\title{
Employment, Family Union, and Childbearing Decisions in Great Britain
}

\author{
Arnstein Aassve \\ Simon Burgess \\ Carol Propper \\ Matt Dickson
}

\section{Contents}

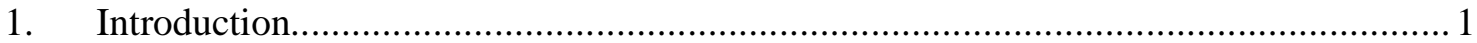

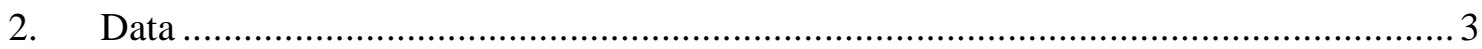

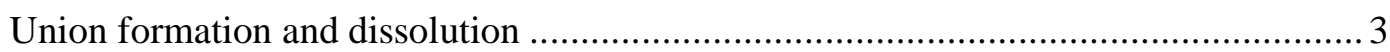

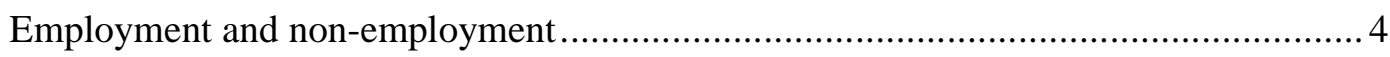

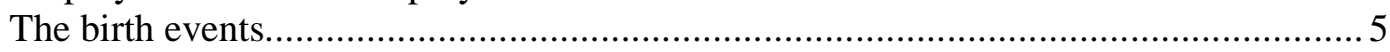

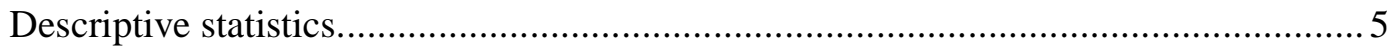

3. Empirical modelling of the demographic and labour market events .......................... 7

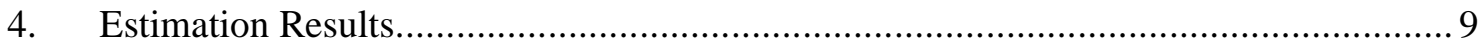

Background variables and education, and endogenous events ................................... 9

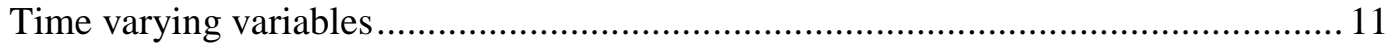

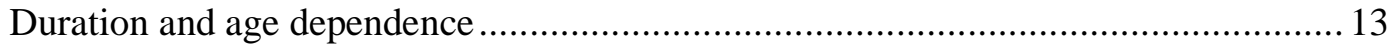

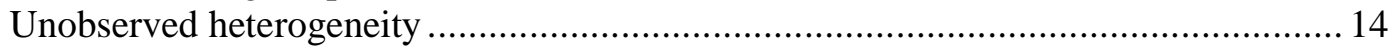

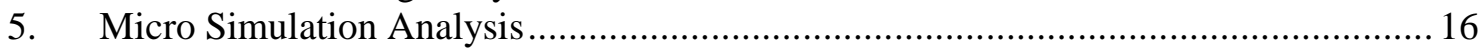

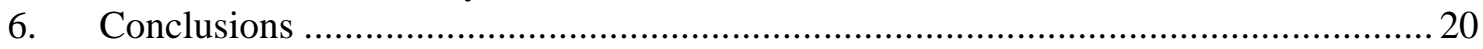

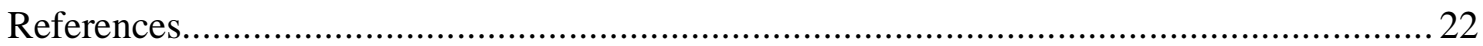

CASEpaper 84

April 2004
Centre for Analysis of Social Exclusion London School of Economics Houghton Street London WC2A $2 \mathrm{AE}$

CASE enquiries - tel: +44 (0)20 79556679 


\section{Centre for Analysis of Social Exclusion}

The ESRC Research Centre for Analysis of Social Exclusion (CASE) was established in October 1997 with funding from the Economic and Social Research Council. It is located within the Suntory and Toyota International Centres for Economics and Related Disciplines (STICERD) at the London School of Economics and Political Science, and benefits from support from STICERD. It is directed by Howard Glennerster, John Hills, Kathleen Kiernan, Julian Le Grand, Anne Power and Carol Propper.

Our Discussion Paper series is available free of charge. We also produce summaries of our research in CASEbriefs, and reports from various conferences and activities in CASEreports. To subscribe to the CASEpaper series, or for further information on the work of the Centre and our seminar series, please contact the Centre Administrator, Jane Dickson, on:

Telephone: $\quad$ UK+20 $\quad$ UK556679

Fax: $\quad$ UK+2079556951

Email: $\quad$ j.dickson@1se.ac.uk

Web site: $\quad$ http://sticerd.lse.ac.uk/case

(C) Arnstein Aassve

Simon Burgess

Carol Propper

Matt Dickson

All rights reserved. Short sections of text, not to exceed two paragraphs, may be quoted without explicit permission provided that full credit, including (๑) notice, is given to the source. 


\section{Editorial Note}

Arnstein Aassve is a lecturer in the Department of Economics, University of Leicester, and a research associate of CASE, London School of Economics. Simon Burgess is Professor of Economics in the Department of Economics and the Leverhulme Centre for Market and Public Organisation (CMPO), University of Bristol, and a research associate at CASE. Carol Propper is Professor of Economics in the Department of Economics and the CMPO, and a co-director of CASE. Matt Dickson is a research assistant at CMPO.

\section{Acknowledgements}

A large part of this work was undertaken while Aassve was working as a research Scientist at the Max Planck Institute for Demographic Research. The authors thank the Institute for outstanding support. We would like to acknowledge Riccardo Borgoni and Stan Panis for their exceptional help and advice in this work. We are grateful to the ESRC for funding this project: grant number R000237943. Aassve would also like to thank RAND for generous support in developing the simulation framework for this analysis. We are also grateful to workshop participants at Southampton, Manchester, Bristol, Leicester, and participants at the ESPE 2003. The responsibility for any errors lies with the authors.

Corresponding author:

Arnstein Aassve

Department of Economics

University of Leicester

University Road

Leicester LE1 7RH

Email: aa128@le.ac.uk 


\section{Abstract}

The paper investigates the relationship between work and family life in Britain. Using appropriate statistical techniques we estimate a five-equation model, which includes birth events, union formation, union dissolution, employment and non-employment events. The model allows for unobserved heterogeneity that is correlated across all five equations. We use information from the British Household Panel Survey, including the retrospective histories concerning work, union, and child bearing, to estimate this model. We obtain well-defined parameter estimates, including significant and correlated unobserved heterogeneity. We find that transitions in and out of employment for men are relatively independent of other transitions. In contrast, there are strong links between female employment, having children and union formation. By undertaking a detailed micro simulations analysis, we show that different levels of female labour force participation do not necessarily lead to large changes in fertility levels. Changes in union formation and fertility levels, on the other hand, do have a significant impact on employment rates.

JEL numbers: J12, J13, J22

Keywords: demographic transitions, marriage, divorce, birth, employment 


\section{Introduction}

Over the last few decades Britain has seen large changes in patterns of employment and family life. The most noticeable change is perhaps the increase in the female employment rate which, in 1999, stood at $72 \%$. At the same time there have also been important demographic changes. Marriage rates have generally declined and have only partly been offset by higher cohabitation rates. Thus, overall both men and women tend to stay single for much longer than was the case in the past. Compared to other European countries, fertility rates have remained high in Britain. Given these observed changes in both family life and employment, it is natural to ask the question to what extent these processes are linked. The contribution of this paper is to address this question using appropriate statistical models, in which individuals' employment decisions are modelled jointly with their fertility and union formation decisions.

It has been argued for instance, that as women have increased their employment rates, and consequently their economic independence, this has marginalized the importance of marriage as an institution to rear children. Increasingly researchers have recognized that many of these demographic and labour market decisions are made jointly and that the transitions are therefore inter-linked. For instance McElroy (1985) suggested that the process of leaving the parental home and finding the first job could not been seen as independent events. An important insight of her work was that from a statistical point of view, failing to control for the jointness of the decisions produced heavily biased parameter estimates. Recently, joint modelling of processes suspected to be interrelated has become more feasible. Willis (1999) proposed a joint model of childbearing and marriage, analysing women's decision to have children outside marriage. Although not estimating an empirical model, Willis's approach highlights the inherently joint decision-making present in demographic processes. An important contribution to the empirical literature is Lillard (1993), who estimated a joint model of fertility and marital dissolution using simultaneous hazard regression. He also estimated the correlation between the two processes and showed that failing to control for simultaneity produced biased parameter estimates. Following this paper, a range of work has focussed on controlling for the possible bias created by the simultaneity of processes. Examples include Lillard and Waite (1993) modelling childbearing and marital dissolution; Brien (1997) investigating the role of the marriage market for different race groups in

the US; Brien et al (1999), Baizan et al (2002), considering the issue of cohabitation, marriage and non-marital childbearing; Upchurch et al (2002) analysing the inter-relationship between union formation, childbearing and educational choice; and van der Klauuw (1996) analysing the relationship between work and marriage. All of these papers demonstrate the importance of 
the jointness of the processes, and that failing to take this into account generally produces biased parameter estimates, which would otherwise be misleading for policy purposes.

Another set of papers consider the impact of income on various dimensions of demographic behaviour. For instance, Duncan and Hoffman (1990), Wolfe et al (2001), and Aassve (2003) consider the impact of economic resources and opportunity costs on women's propensity to have children outside marriage. Aassve et al (2002) investigate the impact of earnings and family income on the decision to leave the parental home and to get married. A central theme in these papers is that income, mainly earnings, is endogenous with respect to the demographic processes under study. They highlight the fact that the income generation process is driven by demographic events, and vice versa. There are nevertheless some important shortcomings of the current literature. Although it is frequently emphasised that work and family formation are interrelated processes, researchers typically analyse only certain aspects of demographic behaviour together with the employment transitions. Furthermore, researchers rarely analyse demographic events in their completeness: typically the issue is about timing of first birth or first union formation, not considering what happens after such events. Here we attempt to provide a fuller picture of both employment transitions and demographic processes.

Our approach is novel in several respects. First we specify a simultaneous hazard regression framework similar to Lillard (1993) that includes birth events, union formation, union dissolution, employment and non-employment events and additionally, allows for unobserved heterogeneity that is correlated across all five equations. Employment, child bearing, and family formation transitions are all specified in separate equations, but estimated in a joint maximum likelihood procedure. This allows us to analyse the impact of employment transitions explicitly, controlling for its potential endogeneity with respect to fertility and union formation. Second, we estimate this model using data from the British Household Panel Survey (BHPS), where panel information (for 1991-1998) is merged with retrospective information provided in 1992 to construct complete histories for employment, child bearing and union formation for all respondents in the panel. We thus create histories stretching back to the 1940s, which enables us to provide estimates for several cohorts of the UK population, and also avoids the problem of left censoring, which is often a problem when using the panel component only. Third, we make use of extensive simulations to provide further insight into the dynamics of these processes, which is not necessarily easy to infer from the parameter estimates alone. 
The next section discusses the data in detail, and section 3 the econometric model. Sections 4 and 5 presents the results, and a final section offers some conclusions.

\section{Data}

The datasets we use are from the British Household Panel Survey for 19911998. The first wave of the BHPS was designed as a nationally representative sample of the population of Great Britain living in private households in the autumn of 1991. Approximately 5,500 households, containing about 10,000 persons, were interviewed. These original sample members are re-interviewed each successive year, and if they split off from their original households to form new households, all adult members of these new households are also interviewed. Similarly, children in the original sample households are interviewed when they reach 16 years of age. Thus, the sample remains broadly representative of the population of Great Britain as it changes through the 1990s. In addition to providing information on respondents within the Panel survey period (1991 onwards) the BHPS asked respondents to provide detailed retrospective work, family and fertility histories in 1992. These retrospective data are matched to the within panel data to construct detailed marriage, fertility and work histories from age 13 for all adult respondents. By using the retrospective histories individual specific behaviour is modelled from the person's 13th birthday, thus avoiding the initial conditions problem normally encountered when estimating duration models based on the panel component only. We have created five detailed event histories for each individual: forming and dissolving a partnership, - having a(nother) child, entering and leaving employment.

\section{Union formation and dissolution}

As cohabitation is an increasing form of union in the UK (either as a precursor to legal marriage or as a substitute), we define marriage as living in union with a person of the opposite gender, regardless of legal marital status. For the within panel data we use the self-reported marital status, which takes the following categories: 'married', 'living as a couple', 'separated', 'divorced', 'widowed' and 'never married'. We classify 'married' and 'living as a couple' as de facto married, with the remaining categories being de facto not married. For the retrospective sample data, we use the dataset BMARRIAG. ${ }^{1}$ This provides the individual's marriage history from the age of 16 years up to the date of interview in wave two. The month and the year of cohabitations leading to

The names of these data sets are the same as they appear in the BHPS data base. 
marriages are provided, as well as dates for which marriages ended as separations. Thus similar de facto marriage information is provided both from the panel and the retrospective part. The retrospective cohabitation histories are completed by using information from the dataset BCOHABIT, which records the details of cohabitations that are never made into legal marriages. ${ }^{2}$ The event histories are consequently constructed by using information from both data sources. We impute missing marital history dates if we know there is a change in marital status and we know the year of the change but the month is missing.

\section{Employment and non-employment}

Individuals are defined as being employed if they are in full time paid employment, part time paid employment or paid self-employment. Individuals who are on long-term leave due to sickness (or on maternity leave ${ }^{3}$ ) are classified as not-employed. An individual is classified as changing employment status only if s/he moves into or out of paid employment. Thus, cases where individuals change employer - but remain continuously employed - are not implemented as a change in employment. Similarly, individuals changing from full time to part time are not recorded with any change. Moreover, individuals moving from full time education to job seeking are recorded with no change. For the within Panel data, we use the variable wJBSTAT which is an annual self-reported employment status. In addition we use wave-by-wave employment history files from wave three to wave eight (wJOBHIST). Each file contains details of all employment status spells since the 1st September in the year before the interview. In cases where individuals have employment changes, the gaps between the annual wJBSTAT are filled with spells from the wJOBHIST files and recoded as 'in paid employment' and 'not in paid employment' as defined above. For the retrospective history we use the BLIFEMST file, which records the individuals' complete paid employment histories from the age that they first left full time education up to 1992. We assume that all individuals are in full time education and therefore non-employed at age 13. The panel and retrospective histories are subsequently used to create two event histories for each respondent, all of which are dated to the month. There are a number of

2 In total there are 1272 such unions, which are never made into legal marriages recorded in the retrospective cohabitation history file. Moreover, out of the 1258 unions that begin after wave $281.3 \%$ are not initially legal marriages. In the retrospective marriage history data, 1403 of the marriages (which is $18.1 \%$ ) begin in cohabitation and 640 (which is $30.8 \%$ of the uncensored retrospective legal marriages) end in separation.

3 We only want to include individuals who are at paid work, therefore maternity leave does not count in this instance as being 'in paid employment'. There are 1039 observations that are maternity leave in the employment history datasets that we use, this represents just $0.8 \%$ of the total number of observations. 
cases where the individual records the start month for a spell as a season rather than a month, and in these cases we apply the BHPS season codes. ${ }^{4}$ The month of July is used for imputation, whenever the month is missing but not the year. Employment events are not imputed if an individual is missing from any years of the panel. The data is treated as censored from the first date the respondent leaves the panel. ${ }^{5}$

\section{The birth events}

Births occurring during the panel years are constructed from the household record of the respondent. In each wave details of new household members are recorded in the dataset wINDALL. The variable wNEWHY provides information about whether the new household member is 'new baby'. If this is the case the event is dated by using month and year variables. In the majority of cases, there is only one birth event in the household in given wave, but we also identify multiple births. ${ }^{6}$ The retrospective history collected in 1992 records the dates of birth of all the respondent's children to that date. The details for an individual's natural children are recorded in the dataset BCHILDNT. ${ }^{7}$ These data are recoded into a monthly panel of data covering the birth events in each individual's life up to the time of their interview in wave two. These data are then merged with the within panel data to create one event history file, which records the conceptions of children, where the conceptions are assumed to have taken place 9 months before the birth date. We do not model children leaving home, so do not create a file of children leaving home dates. These data are also used to create stocks of each process as well as durations. In the case of stocks of children, we assume that children leave home at 21 , so decrease any positive stock by 1 at the date at which the oldest child will be 21 .

\section{Descriptive statistics}

Table 1 presents statistics for the transitions. The table provides mean duration until birth, union formation, union dissolution, employment, and nonemployment, all measured in years. Note here that all durations include also

4 The BHPS season codes are: winter=January, spring=April, summer=July and autumn=October.

5 The number of individuals who become censored after each wave are as follows: after wave two (872), wave three (920), wave four (700), wave five (398), wave six (349), wave seven (386). There are 6839 individuals who only become censored at the end of the data we use (wave 8,1998 ).

The great majority of individuals only ever have one birth event in any one wave. There are nine households where there are two birth events within one wave and one household where there are three birth events within one wave.

$7 \quad$ We use only the records of individual's natural children. 
those individuals censored at the end of the survey. In addition, the table indicates the proportions experiencing the events. The relevant figures are given in the first and third columns (i.e. the column shown as 'sample'). From the table we see that the mean duration until first childbearing is 13.57 years for women, and 16.46 years for men, so mean ages of first birth are 26.57 and 29.46 years respectively. The second row shows the mean time until second birth, starting from the time of the first birth. Thus the mean times until the second childbearing events are 4.36 and 4.62 for men and women, which correspond to mean ages of 30.9 for women and 34 for men. The data indicate that once the first birth has occurred, both men and women accelerate the timing of the second birth, whereas third or fourth births generally tend to take place at a much later age. About 68 percent of all women and 58 percent of all men are recorded as having at least one child and the percentages are slightly higher for the proportion of those who have one child that go on to have at least one more child. Given two children, relatively few go on to have a third birth.

For union formation, the mean age of first union formation is 23.37 for women and around 26 for men. The mean time until first union dissolution is quite long, indicating that a large proportion of those entering the first union tend to remain in this union, and in the majority of cases, until the censoring date. Of those who experience a union dissolution (35 percent of women and 28 percent of men) the mean time to second union is 5.26 years for women and 4.10 years for men.

Employment and non-employment transitions, on the other hand, are much more frequent events. Both men and women find employment on average at the same age, and interestingly, almost all women in this sample have at least one employment spell. The difference between men and women becomes apparent when looking at any subsequent employment transition, as well as the nonemployment transitions. The mean time for the first non-employment transition is 7.47 years for women and 14.53 years for men. Furthermore, 80 percent of women who were employed at least once become non-employed at some stage in their career. The equivalent figure for men is considerably lower (53 percent). Once non-employed, men tend to find employment considerably quicker than women. For instance, the time until second employment for women is on average 4.89 years, whereas for men the mean time is only 1.62 years, and similar discrepancies exist between men and women for subsequent employment transitions. 


\section{Empirical modelling of the demographic and labour market events}

In our model we specify five hazards, which arise from three processes (childbearing, union formation, and employment transitions). We assume that these hazards are not exogenous to each other and depend on both the past occurrence of the own and other processes, the parity of own and other events, on duration, age, a set of time invariant observed characteristics, and time invariant unobserved characteristics. The set of hazards is as follows:

$\ln h_{t}^{B}(t)=b_{1} f(M(t), D(t))+b_{2} f(E(t), U(t))+\underline{b}_{3} T^{B}(t)+\underline{b}_{4} A^{B}(t)+\underline{b}_{7} \underline{x}^{B}+\underline{b}_{8} \underline{P}^{B}+\varepsilon^{B}$

$\ln h_{t}^{M}(t)=\sum_{i=1}^{6} m_{i} B_{i}(t)+m_{7} f(E(t), U(t))+\underline{m}_{8} T^{M}(t)+\underline{m}_{9} A^{M}(t)+\underline{m}_{10} \underline{P}^{M}+\underline{m}_{11} \underline{x}^{M}+\varepsilon^{M}$

$\ln h_{t}^{D}(t)=\sum_{i=1}^{6} d_{i} B_{i}(t)+d_{7} f(E(t), U(t))+\underline{d}_{8} T^{D}(t)+\underline{d}_{9} A^{D}(t)+\underline{d}_{10} \underline{P}^{D}+\underline{d}_{11} \underline{x}^{D}+\varepsilon^{D}$

$\ln h_{t}^{E}(t)=\sum_{i=1}^{6} e_{i} B_{i}(t)+e_{7} f(M(t), D(t))+\underline{e}_{8} T^{E}(t)+\underline{e}_{9} A^{E}(t)+\underline{e}_{10} \underline{P}^{E}+\underline{e}_{11} \underline{x}^{E}+\varepsilon^{E}$

$\ln h_{t}^{U}(t)=\sum_{i=1}^{6} u_{i} B_{i}(t)+u_{7} f(M(t), D(t))+\underline{u}_{8} T^{U}(t)+\underline{u}_{9} A^{U}(t)+\underline{u}_{10} P^{U}+\underline{u}_{11} \underline{x}^{U}+\varepsilon^{U}$

where $h_{t}^{j}, j=B, M, D, E, U$ are the hazards of a birth, union formation, union dissolution, employment and non-employment respectively. Equation (1) is the $\log$ hazard rate of experiencing a birth event, equation (2) the log hazard of a union event, equation (3) the log hazard of a union dissolution, equation (4) the log hazard of an employment event, and equation (5) is the hazard rate of experiencing an non-employment event.

The functions $f(.,$.$) denotes the endogenous variables, and are constructed as$ time varying dummy variables. For instance marital status is included as a time varying variable in equations 1,4 and 5, and takes the value 1 in the segments which an individual is married (or in a union), and zero otherwise. Employment status is implemented similarly. Individuals may have many children and experience several unions, employment and non-employment spells. In other words, events might be repeated over time. We do not specify separate equations for different spells: for instance, the equation for a marriage event, equation (2), includes first, second, and up to the sixth birth. But as the process of, say, first child bearing might be very different from the process of second 
birth event, each hazard is modelled as a function of a set dummy variables $P^{j}$, where $j \in B, M, D, E, U$, to control for the parities of the own event. In addition, we include detailed controls for age, which is captured by $A^{j}(t)$. This is a vector of $N_{A}+1$ spline variables whose coefficients are allowed to differ between intervals separated by $N_{A}$ nodes. Denoting the nodes as $w_{k}$, we can define the spline variable for the $k$ th interval as:

$$
A^{j}(t)=\max \left[0, \min \left(t-w_{k-1}, w_{k}-w_{k-1}\right)\right] ; j \in(B, M, D, E, U)
$$

The baseline hazard function, $T^{j}(t)$, is defined in a similar way, a piecewise continuous linear Gompertz function. By specifying several node points, the formulation allows for a variety of patterns of the duration dependence in the hazard function. To complete the specification of equations (5) - (9) we include a range of non time varying variables, denoted $x^{j}$. These are education (in 5 groups), cohort of birth (in 4 groups), ${ }^{8}$ parental socio-economic status, ethnic origin, and a dummy variable indicating whether the respondent lived with both parents at age $14 .^{9}$ Leaving each $\dot{\varepsilon}^{\dot{\varepsilon}}$ as independent univariate random variables will capture unobserved heterogeneity within each process, but not capture any correlation in unobserved heterogeneity across processes. To deal with this we specify $\varepsilon^{\dot{\varepsilon}}$ to have a multivariate joint normal distribution. Formally:

$$
\left(\begin{array}{l}
\varepsilon^{B} \\
\varepsilon^{M} \\
\varepsilon^{D} \\
\varepsilon^{E} \\
\varepsilon^{U}
\end{array}\right) \sim N\left(\left(\begin{array}{l}
0 \\
0 \\
0 \\
0 \\
0
\end{array}\right),\left(\begin{array}{ccccc}
\sigma_{B}^{2} & \rho_{M B} & \rho_{D B} & \rho_{E B} & \rho_{U B} \\
\rho_{B M} & \sigma_{M}^{2} & \rho_{D M} & \rho_{E M} & \rho_{U M} \\
\rho_{B D} & \rho_{M D} & \sigma_{D}^{2} & \rho_{E D} & \rho_{U D} \\
\rho_{B E} & \rho_{M E} & \rho_{D E} & \sigma_{E}^{2} & \rho_{U E} \\
\rho_{B U} & \rho_{M U} & \rho_{D U} & \rho_{E U} & \sigma_{U}^{2}
\end{array}\right)\right)
$$

By estimating the correlations between equations we are in effect able to control for the fact that the five processes might be endogenous to each other. To illustrate the problem, assume for the moment that we only estimated the first two equations. Furthermore, let us assume that the correlation between childbearing and union formation, here given as $\rho_{B M}$, is positive, but that we fail to control for this correlation in the regression. Under these circumstances the

8 The cohorts are defined by decade of birth beginning in 1940. The lowest educational group have no qualifications; the highest have university level qualifications.

As it stands this specification does not include any interaction terms. Clearly several interaction formulation could be interesting and bring a deeper understanding to individuals' behaviour. However, currently the model contains 185 parameters, and estimation is not trivial. Given that the current specification is able to replicate the original data reasonably well we decided not to include further covariates. 
estimates of the direct effect of union formation (the time varying variable) in the childbearing equation, and the time varying birth variables in the union formation equation, will be biased. In fact, as long as the true correlation is positive there will be an upward bias in the direct effects. ${ }^{10}$ In a system of five equations, where each event interacts with each of the others, it becomes more difficult to predict the direction of the bias. An additional important feature of the unobserved heterogeneity terms is that they are assumed fixed over an individual's lifetime. Clearly, unobserved characteristics influencing the hazard might change as the various events take place. ${ }^{11}$

\section{Estimation Results}

This section presents the parameter estimates of the econometric model (see Tables 2A-2E).

\section{Background variables and education, and endogenous events}

We start by discussing the estimated coefficients of the non-time varying background variables. These show that family background is an important determinant for an individual's family formation events, whereas it has less impact on the employment transitions. Both men and women coming from disrupted families have more children, form and dissolve unions quicker. The effects are weaker for the non-employment transitions, although we do find that women from disrupted families are more likely to leave employment, which is consistent with the fact that they have more children. Men and women from non-white ethnic origins show quite different behaviour to the rest of the population. They generally tend to delay union formation, but have a considerable higher fertility rate once in a union. They also have a lower rate of entering employment, whereas there is no difference in terms of leaving employment. Parental occupational status has a more limited impact. It is

This argument rests on the assumption that the multivariate normal distribution is able to capture the unobserved heterogeneity reasonably well. Heckman and Singer (1984) argue against using parametric distributions since the specific choice of the distribution function might affect the parameter estimates. However, this conclusion has later been contested (see for instance Ridder (1987) and references therein). It has been argued that different impacts of choosing a parametric distribution is just as likely to be affected by using an inflexible function for the baseline hazard function. If the baseline is flexible, i.e. the piecewise continuous linear Gompertz formulation used here, it is not clear that the parametric choice of the unobserved heterogeneity should have much impact on the parameter estimates.

11 See Aassve et al (2002) for a specification where the unobserved heterogeneity terms are different, but correlated, across time. 
strongest in the fertility transitions, where a high male parental socio-economic status is associated with a significant reduction in the fertility rate. Mother's occupational status has very little or no impact. The impact of father's occupational status on entering employment is negative both for men and women. This is somewhat surprising given that we also control for educational attainment. A possible explanation is that the father's occupational status is positively correlated with family income. The negative impact suggests that young individuals from wealthy family backgrounds tend to delay entry to employment, which might be due to longer time spent in education.

We now turn to the impact of education. ${ }^{12}$ Most of the estimates are consistent with previous findings, although we do find some unexpected non-linear effects. For childbearing, we find that highly educated women have a lower rate of child bearing. Furthermore, there is a monotonic gradient for the five categories of educational attainment. The impact of education on having children is weaker for men and only men with higher educational attainment levels have a fertility rate that is significantly lower than that of the other education groups. For union formation, the impact is very similar to those of fertility, although the magnitude of the effects is generally smaller. These findings are generally consistent with our expectations. Education generally delays both fertility and union formation and the impact is generally monotonic. For union dissolution on the other hand, educational level has no significant impact. In terms of entering employment, the results are more mixed. Women with medium levels of qualifications have a higher entry rate into employment compared to those with lower education. Women with very high educational attainment have a considerable lower transition rate into employment than all other groups. For men the impact is slightly different. Low and medium levels of education do not seem to have any differential impact on the entry into employment. However, as for women, those with the highest educational attainment have a lower rate of entry into work. Interestingly, higher education among men is negatively associated with leaving employment. Consequently the results suggest that, although highly educated men are less likely to leave employment, once they have left, they spend longer searching for the next job. For women the educational effect on non-employment is also negative, but there is no monotonic gradient. It is important to keep in mind that these patterns might be driven by the fact that both men and women who spend longer time in education will necessarily delay entry into employment.

12 Note that we treat education as exogenous, though properly it should be modelled as part of the set of choices individuals make about their post compulsory school leaving behaviour. However, modelling the level of education would add too much complexity. 
Our estimates indicate important behavioural differences between the four cohorts. In general we find that the younger cohorts have lower fertility rates and a lower rate of entering unions. Once in a union they are considerably more likely to dissolve the union, compared to the oldest cohort, which indicates that individuals in the younger cohorts tend to spend longer time being single. The results are more mixed for the employment and non-employment transitions. Among women we see that the second oldest cohort enter employment at a higher rate than the oldest cohort, whereas there is no significant difference between the oldest cohort and the two youngest cohorts. For men, compared to the oldest cohort, the individuals in the younger cohorts all have lower transition rates into employment. For both genders there are clear positive gradients for entry into non-employment, indicating that the younger cohorts have a much higher transition rates out of work than the oldest cohort. The combination of these trends indicates that individuals in the younger cohorts, particularly the men, spend more time unemployed than those in the older cohorts.

\section{Time varying variables}

We start by analysing the impact of marital status and employment status on child bearing. Note that marital status incorporates cohabitation, and employment includes full time and part time work. The estimates in Table 2A indicate that marital status has a large positive impact on fertility events, and that the effect remains strong when controlling for unobserved heterogeneity. As we would expect, being in employment has a negative impact on conceptions. Although the parameter is highly significant, it is not extremely large, implying that working is not a particularly strong deterrent to having children. It is possible that the relatively weak effect is somewhat influenced by the fact that we incorporate part time and full time work into the same category. It is possible, for instance, that women in full time work have a much lower fertility rate than women working part time. Obviously the recorded employment spells might mask transitions between part time and full time work, which might play an important role in fertility decisions. ${ }^{13}$ The positive impact of employment for men on having children is also according to expectations. The parameter is highly significant, but again the magnitude is somewhat small. Note, however, that the parameter estimate here averages over all birth orders. Thus it is possible that the impact would have been stronger for timing of first birth, and even weaker for subsequent births.

While it is noted that transition to part time work usually occurs after the birth of a child rather than prior to conception, it may be the case that the negative effect on fertility of transition into full time work from part time work is masked by the inclusion of part time work in the employment definition. 
When considering the impact of child bearing on union formation, we see that the impact very much depends on the birth order. Note here that the birth events represent the stock of children and should be interpreted accordingly. For instance, experiencing a first birth has a strong positive impact on forming a union, and this is the case for both genders. However, having a second birth outside a union actually lowers the rate of union formation rate. The opposing signs of the first and the second birth events are interesting. The positive impact of the first birth event is consistent with economic theories in that individuals consider a cohabiting union or a marriage more beneficial once they have acquired marital specific capital. However, there might also be normative forces at play, in the sense that individuals might feel a pressure to 'legitimise' the child. The negative sign of second birth-event indicates that those who do not form a union after the first birth are at a disadvantage in the marriage market when they have the second child. ${ }^{14}$ The subsequent birth events have no significant impact on union formation. Work status has a positive and strongly significant impact on union formation for both men and women, a finding consistent with most previous research.

Turning to the union dissolution hazard, we find parameter estimates consistent with our expectations. The negative impact of first and second birth on dissolution indicates the role of children as marital specific capital. Thus having children reduces the separation rate. ${ }^{15}$ Our specification does not include duration splines for the birth events, so we do not examine the impact of the age of the children on the rate of dissolution. ${ }^{16}$ It is noteworthy that the impact of children becomes stronger once we control for unobserved heterogeneity. In fact, the negative impact of the second birth event is only significant for women when unobserved heterogeneity is included. The third birth event does not have any statistically significant impact on dissolution. Higher birth orders generally have a positive impact, but these variables are not particularly well defined due to small sample sizes. The impact of work status on divorce is not particularly strong, especially for men, independent of whether unobserved heterogeneity is

14 The second birth event outside a union will also include women who might have had the first birth within a union. We allow for individual specific fixed effects in the modelling process which can take into account tastes for marriage and therefore control for this.

15 The individual fixed effects control for tastes for marriage such that it is not simply the case that children are born in more stable relationships. Therefore though there are not fixed effects for specific unions to control for the stability of a union, the effect of tastes for union are controlled for somewhat in the individual fixed effects.

16 See, for instance, Lillard and Waite (1993) who show how dissolution depends on the age of the children. 
controlled for. For women, on the other hand, work has positive impact only when we control for unobserved heterogeneity.

The rate of entering employment is negatively associated with a first birth event. Although the impact is negative for both genders, it is considerably weaker for men. This negative impact for men is somewhat surprising, as the financial costs associated with childbearing, and the traditional division of labour between men and women just after child-birth, would suggest a greater incentive for men to enter employment. For second births, there is no significant effect for women, whereas there is still a weak negative effect for men when unobserved heterogeneity is included. For higher birth orders the negative impact for women and men (apart from the third birth order) persists. Being in a union reduces the employment rate for women, independent of whether the specification controls for unobserved heterogeneity or not. For men, there is a strong positive impact, but interestingly, this disappears once we control for unobserved heterogeneity.

Our estimates of the relationship between entering non-employment and childbearing show interesting, although not entirely unexpected results. For women, the first birth event has a strong and positive impact on leaving employment, whereas for men there is no significant effect. The impact of the second birth event on entering non-employment is negative and significant for women, suggesting that those having the second child are more likely to hang onto to their jobs, implying that more women now return to work immediately after the maternity leave. Again, the birth event does not have any impact on men's employment decision. Marital status has a similar effect as the birth events. That is, women in a union have a considerably higher rate of entering non-employment compared to those who are single. For men the impact is negative, although this again disappears once we control for unobserved heterogeneity.

\section{Duration and age dependence}

Tables $3 \mathrm{~A}-3 \mathrm{E}$ report the parameter estimates of the baseline hazard and age splines. These estimates provide a picture of the duration dependence and the age effect in the five processes. Starting from Table 3A, which reports the estimates for the birth events, we note that the hazard is initially increasing and then declining for all intervals, apart from a positive jump in the second last interval. It is important to remember that this refers to the baseline for all birth events. As is well known in the literature (e.g. Newman and McCulloch (1984)), the shape of the baseline for the first birth event is very different compared to any subsequent births. In the former the shape of the baseline tends to have a pronounced inverted U-shape. Here, where the baseline parameters refer to the average of all birth parities, the shape is much less pronounced. Looking at the 
impact of age we see a much more distinct pattern. The rate of childbearing increases sharply with age initially, then becoming flat or slightly decreasing. ${ }^{17}$ For union formation we find less marked patterns, especially in terms of the baseline hazard. Again, this is in contrast to the typical shape of the baseline of first union event, which is normally strongly increasing and then declining. Again the age splines are more prominent and increasing until age 23 before they start to decline weakly. For dissolution the patterns are more mixed. The baseline hazard is flat for the first two intervals, then sometimes declining and sometimes increasing, every time at very small magnitudes. A mixed pattern also appears for the age splines. For men it is difficult to estimate more than two age splines. Overall the estimates for dissolution indicate little duration dependence or age effects.

The age effect for employment transitions is considerably stronger. The hazard increases strongly with the first age interval, then rises at a slower rate and then becomes approximately flat. The risk of employment has negative duration dependence, although the pattern is not monotonic. In other words, the risk of employment falls the longer the individual remains unemployed, although the hazard eventually becomes flat. For non-employment transitions our estimates indicate very little duration dependence although there does seem to be weak age dependence at the early ages.

\section{Unobserved heterogeneity}

The estimates of the parameters of the unobserved heterogeneity terms are reported in Table 4. The first panel gives the estimates of the standard errors of the five equations. The impact of the unobserved heterogeneity is particularly pronounced for the shape of the baseline hazard, the parity variables, and the age effect. For women most of the standard errors are close to unity, except for the employment hazard. ${ }^{18}$

The second panel of Table 4 reports the estimates of the correlations between the error terms. Before looking at the correlations in detail, it is useful to say a few words about their interpretation. In the case of single spell-multiple processes, a positive correlation, say, would indicate that those two events are

17 An interesting question is whether only one hazard rate function for all birth parities is a sufficient specification - the alternative being separate hazard function for each birth-parity. However, as the next sections shows, computing descriptive statistics from simulating the model and comparing them with the original sample shows a quite close fit, which we take as an indication that our specification is sufficient in replicating the observed transition patterns.

18 Put differently, compared to the other processes, the variation in employment transitions among women seem to be fairly well captured by the observed covariates. 
determined jointly. For instance, a positive correlation in a model of timing until first childbearing and first union formation, would suggest that these decisions were not made independently of each other. Or put differently - individuals would rarely make a decision about marriage independently of having had the first birth. In our specification events are repeated: individuals may have many marriages and they may have many children. As such a positive correlation reflects that the more likely you are to have children (not only the first child) the more likely you are to get married - that is, it may reflect long run taste and capabilities. ${ }^{19}$

Looking at the correlations we see that they are mostly non-zero and significant, indicating the endogeneity of the processes. In addition to the correlations between fertility (childbearing) and union formation, there is a positive correlation between childbearing and union dissolution and between childbearing and employment and non-employment. Thus, individuals more prone to childbearing are also more likely to have more marriages and more employment spells i.e. have a more variable marriage and employment history. Interestingly, and not unexpectedly, the correlations between childbearing and employment and childbearing and non-employment are considerably smaller for men.

The estimates also reflect a significant positive correlation between union formation and dissolution. The estimate indicates that there are women (the correlation for men is not significant) that have a strong preference for living in a union but who at the same time are not satisfied with their current union. Thus, they have stronger tendency to move into and out of unions. The positive correlations between fertility and union formation, fertility and union dissolution, and union formation and union dissolution, are all consistent with the findings of Upchurch et al (2002) using US data.

We also find a strong positive correlation between union formation and employment. Thus those who are more likely to form a union are also more likely to get employment quickly. There is little evidence to suggest any correlation between union and non-employment, and employment and union

19

The issue of interpretation is more subtle than this. Frequently in the demography literature, unobserved heterogeneity is referred to as differences in taste for family life. Those who marry and have the first birth quickly (normally reflected by a positive correlation) are often said to have a preference for family life, which in the data is unobserved. But of course unobserved heterogeneity is by definition unobserved. Consequently we cannot know for sure what underlies a positive or negative correlation. However no data source is likely to be rich enough to provide much clues about the exact nature of the unobserved factors. 
dissolution. In addition, there is little to suggest that there are any common unobserved factors driving employment and non-employment transitions. This is an interesting result, as it suggests that, controlling for the other endogenous processes, there is no significant correlation between the two. In other words, those who tend to find employment quickly, conditioning on the observed covariates, do not necessarily have a higher rate of becoming non-employed. As such, the case is different to union formation and union dissolution, where the correlation is strong and significant for women. In summary, the effect of controlling for unobserved heterogeneity is to affect the coefficient estimates on the stocks of the 5 processes, on the baseline hazard and age. In addition, the estimated unobserved heterogeneity between processes is somewhat different to that which has previously emerged from estimates of only a subset of the processes considered here.

\section{Micro Simulation Analysis}

As a means to provide further insight into the inter-relationships between these processes we undertake a detailed micro simulation analysis. The basic principle behind the simulations is to make random draws from the uniform distribution in which the random values are converted to simulated durations, via the inverted survivor functions. ${ }^{20}$ Fortunately, simulating a system of simultaneous hazards is quite similar to the case of single equation models with repeated spells, or any fully sequential model, such as the competing risk model. Despite the fact that the principle remains the same, simulating a system will necessarily involve a higher level of complexity. This is mainly driven by the fact that any of the events taking place must be incorporated as time varying variables in the other equations. In other words, any time varying events included as regressors in the estimation procedure must also be incorporated in the simulations. ${ }^{21}$

Here every individual is simulated from the age 13. From this age, we simulate the timing of 1) the first birth event, 2) the first union event, and 3) the first employment event. We do not simulate timing of non-employment and union dissolution, since at age 13 all individuals are assumed - and consistent with the original data - not to be working nor in a union. The lengths of the three See Aassve et al (2002) and Aassve (2003) for applications of this approach.

21

As an example, consider the two equations of birth events and union formation. If an individual is simulated to marry prior to any birth events, the marriage union event has to be included as a time varying variable in the birth equation. Similarly, if a person is simulated to experience first childbirth prior to marriage, this event must be included as a time varying variable in the marriage equation. 
simulated durations are compared, and the shortest is selected and taken to be the first event for this simulated individual. Based on the timing of the event the baseline duration dependence and the age dependency are updated. That is, if the length of the first simulated duration is five years, then the next events are simulated from age 17. Starting from the time of the first event, now assuming that the individual is in a union, a birth event, a union dissolution event, and an employment event are simulated. Again, the shortest of the three durations are selected and recorded. This procedure is repeated until the censoring date is reached. Note being in a union and being single are taken to be mutually exclusive states as are being in employment and being unemployed. Fertility events, in contrast, are repeated and irreversible events. Consequently, an individual will always be at risk of another child, provided he or she has not reached the censoring date imposed in the original data. ${ }^{22}$

The simulations are performed separately by gender, with 52600 replications for women and 49980 replications for men. These simulated individuals have the same background characteristics (such as ethnic background, cohort, parents' characteristics, and so on) as the original sample. In contrast, the time varying variables will depend directly on the simulated paths, as they are generated from the simulation themselves. Simulation of the unobserved heterogeneity terms is relatively straightforward. Each simulated individual is given a value drawn from the five-dimensional joint normal distribution, as shown in equation (7), and reported in Table 4. This value is simply added to the log hazard, which is used to construct the inverted survival function.

Table 1 compares descriptive statistics from the data and the simulations. The descriptive statistics from the simulations coincide well with those of the sample. This is particularly the case for the demographic transitions. For the first three birth events it is clear that the differences are very small. The same is the case for union formation and union dissolution. The discrepancies become somewhat larger for events that are less frequent in the original sample (e.g. the fourth birth). For the employment and non-employment transitions the fit is also satisfactory, although again the discrepancies become larger as events become less frequent.

We classify individuals into overall states defined by the combination of marital, employment and child states. 16 states are defined by the 2 marital states $* 2$ employment states $* 4$ child states. Occupancy of these overall states differs by gender. The most common state for females is single, employed, no children (21\%), followed by married, employed, no children (17\%). 6\% of

22 The censoring date for childbearing was set to 45 years of age for women, and 55 years of age for men. 
females are single, not employed, with no children, and around $4 \%$ are single, not employed with children. For men, the most common group is single, employed, no children (31\%), followed by married, employed, no children $(17 \%)$. Around $9 \%$ are single, unemployed, with no children, and just under $1 \%$ are single, not employed with children.

These state occupancy patterns for women and men against age are illustrated Figures 1 and 2, respectively. To simplify the presentation we graph only selected states for each age and by cohort. The 4 groups represented for females are 'single, non-employed, parents', 'single working with no children', 'married, not working, with children' and 'married, working, with children'. These states account for about 66 percent of all female observations. All 4 graphs show the sharp fall in the 'single, working with no children' group between the ages of 18 and 30 and the rise in the number married with children (both working and not working). The cohort differences can again be seen clearly: across cohorts, the fall in the 'single, working, no children' group takes place at later ages the younger the cohort. The two graphs for the two older cohorts shows the relative increase with age in the share of married women with children that are employed compared to those who are not employed.

Figure 2 traces out the occupancy of 4 states by age for 4 cohorts for males. The four states are 'not married, not employed, no children', 'not married, employed, no children', 'married, not employed, children' and 'married, employed, with children'. Together, these groups account for 73 percent of all observations. The graphs for all four cohorts show the fall in the two unmarried groups over time and the rise in the number married working with kids. This fall and rise take place at a younger age the older the cohort. Compared to females, the number who are married with children but not employed is much lower, reflecting the higher employment rate for men.

Of crucial interest in this analysis is the extent to which fertility, union formation and employment influence each other. For instance, what is the impact on fertility and union formation rates from an increase in employment among women? Or similarly, what is the impact on fertility and employment levels from increasing the rates at which men and women form unions? Given the complex nature of the model, predominantly driven by non-linearities and intricate feedback mechanisms, the parameter estimates alone are not necessarily very useful in answering these questions. In contrast, simulations facilitate informative sensitivity analysis in a simple way. Our approach is the following. For each of the three processes, we increase the hazard of each event occurring in turn. For the fertility process we increase the intercept by $10 \%$, for unions we increase the intercept of entering a union by $10 \%$ and decrease the intercept for dissolving by the same amount, and for employment we increase 
the intercept by $10 \%$ for entering and decrease by $10 \%$ for leaving employment. Descriptive statistics from these simulations are reported separately for men and women in Tables 5 and 6 , respectively. In the first block we report the proportion of individuals who have the first birth by certain ages. The second block refers to second births, but note here that the proportions are calculated against the total sample - as opposed to the sample of individuals having experienced first birth. In the bottom block we report the mean time spent in union, being single, not working, and the mean time spent working. The tables make it clear that the primary impact of a change in the hazard of the each event (or pair for marriage and employment) is to change the probability distribution of that event itself. For example, simultaneously increasing the marriage and decreasing the divorce hazard (third column) increases the mean time spent in a union from 15.4 to 18.2 years - for women. For men it increases from 12.67 to 16.0 years (Table 6, third column). Increasing the probability of employment and decreasing the probability of non-employment increases the mean time spent working from 15.9 to 16.6 years for women and from 20.50 to 23.68 years for men. The impact of increasing the hazard of having children is reflected in the second column of the two tables. Of interest is the relative 'cross impact' on the other processes. That is we are interested in the effect of increasing fertility on union formation and employment. As is clear these cross effects are considerably smaller than the effect of the process itself. For instance, increasing the fertility rate increases the mean time spent in union from 15.4 to 15.7 years for women. Moreover, it reduces the mean time spent working from 15.9 to 14.2 years - again for women. Looking at table 6 we see that employment for men is considerably less sensitive to the increase in fertility employment increases from 20.5 to 20.6 years. Increasing the rate of staying in a union has also a significant impact on both fertility and employment for women. However, increasing the rate of working has very little impact on both fertility and union formation. For instance, the mean time spent in a union is reduced from 15.38 to 15.34 years - which is only marginal effect. The reason for this small impact is mainly driven by the fact that the employment parameter in the union and fertility equations is quite small. Moreover, looking back at the estimates in Tables $2 \mathrm{~A}-2 \mathrm{C}$ we see that employment has a negative impact on fertility, thus decreasing the number of children born. In contrast, increased employment will have a positive impact on the time spent in a union - despite employment also having a positive impact on dissolution. At the same time, increased time spent in a union - as a result of increased employment, will have an indirect effect in that union is positively associated with fertility. Interestingly these effects net each other out - producing only very small net effects. The same feedback mechanisms are in place for men, though looking at Table 6 we see that the impact of increasing employment on fertility and union is marginally larger than it is for women. Another factor that is important in this setting is that we have defined employment to include part time employment. 
Thus, women working part time are treated in the same way as those working full time. It is possible that if separated - the impact of the two employment states would have quite different impact on fertility levels, which would also show up in the simulations.

\section{Conclusions}

This study emphasises the link between employment transitions and demographic processes in Britain. In particular we have focussed on the extent to which these processes are inter-related, and subject to joint decision making. The empirical analysis is implemented by estimating a complex hazard model with five hazards, each with unobserved heterogeneity, which is allowed to be correlated across the five processes. We estimate this model using data on individuals stretching from the 1940s to the late 1990s.

Our estimates are, in general, well defined and accord with findings from previous research. In particular we find being in employment is negatively associated with fertility events for women, but with the opposite effect for men; employment has a strong positive effect on union formation for both men and women, has a positive impact on union dissolution for women, but no impact among men. Moreover, family events have important effects on employment and non-employment transitions, most of which are of the expected direction. Our approach also confirms the importance of controlling for unobserved heterogeneity. Both the standard deviations, and the correlations between the error terms, are statistically significant in most cases, and often quantitatively significant too. Importantly, the estimates show that employment events are in most cases related to demographic transitions.

An important contribution of our approach is the use of simulations. The empirical model is highly complex, and interpretation based on assessing the parameter estimates alone is generally hard. Moreover, the parameters do not provide easy calculation of the magnitude of the various cross effects. The use of simulations enables us to trace out the evolution of family states over time for any individual, and provides therefore an extremely powerful tool for assessing the sensitivity of the various parameter estimates. The simulations show that increasing the rates of any of the processes has a strong impact on that process itself, whereas the cross effects are much weaker. This is particularly the case for employment, where any change has very little impact on overall rates of fertility and union. Interestingly we find that changing the fertility or the union process, does have a significant impact on employment rates. Our finding that fertility rates are insensitive to changes in employment rates is not inconsistent with the overall patterns. Though employment has increased among women 
over the last few decades, there has not been a comparable decline in fertility, which is reflected in our micro level analysis. 


\section{References}

Aassve, A. (2003), 'The Impact of Economic Resources on Premarital Childbearing and Subsequent Marriage among young American Women', Demography 40(1): 105-126.

Aassve, A., S. Burgess, A. Chesher, and C. Propper (2002), 'Transitions From Home to Marriage among Young Americans', Journal of Applied Econometrics 17(1): 1-23.

Baizán, P., A. Aassve and F.C. Billari (2002), Institutional arrangements and life course outcomes: The interrelations between cohabitation, marriage and first birth in Germany and Sweden, WP-2002-026. Rostock: Max Planck Institute for Demographic Research.

Brien, M.J. (1997), 'Racial Differences in Marriage and the Role of Marriage Markets', Journal of Human Resources 32: 741-778.

Brien, M., L. Lillard, and L. Waite (1999), 'Interrelated Family-Building Behaviors: Cohabitation, Marriage, and Non-Marital Conception', Demography 36(4): 535-551.

Duncan, G.J. and S.D. Hoffman (1990), 'Welfare Benefits, Economic Opportunities and the Incidence of Out-of-Wedlock Births among Black Teenage Girls', Demography 27(4): 519-557.

Heckman, J.J. and B. Singer (1984), 'A Method for Minimising the Impact of Distributional Assumptions in Econometric Models for Duration Data', Econometrica 52: 271-290.

Lillard, L. (1993), 'Simultaneous equations for hazards: Marriage duration and fertility timing', Journal of Econometrics 56: 189-217

Lillard, L.A. and L.J. Waite (1993), 'A joint model of marital childbearing and marital disruption', Demography 30(4): 653-681

McElroy, M.B. (1985) 'The Joint Determination of Household Membership and Market Work: The Case of Young Men', Journal of Labour Economics 33: 293-316.

Newman J.L. and C.E. McCulloch (1984) 'A Hazard Rate Approach to the Timing of Births', Econometrica 52: 939-961.

Ridder, G. (1987), The sensitivity of duration models to misspecified unobserved heterogeneity and duration dependence, Report AE 7/87: 141, Department of Actuarial Science and Econometrics, University of Amsterdam. 
Upchurch, D.M., L. Lillard, and C.W.A. Panis (2002), 'Nonmarital Childbearing: Influences of Education, Marriage, and Fertility', Demography 39(2): 311-330.

van der Klauuw, W. (1996), 'Female Labor Supply and Marital Status Decisions: A Life Cycle Model', Review of Economic Studies 63(2):199235.

Willis, R. J. (1999), 'A Theory of Out-of-Wedlock Childbearing', Journal of Political Economy 107: S33-S64.

Wolfe, B., K. Wilson and R. Haveman (2001), 'The Role of Economic Incentives in Teenage Non-marital Childbearing Choices', Journal of Public Economics 81: 473-511. 
Figure 1: Distribution of selected states by age and cohort: baserun, women

Selected states by age, 4 cohorts
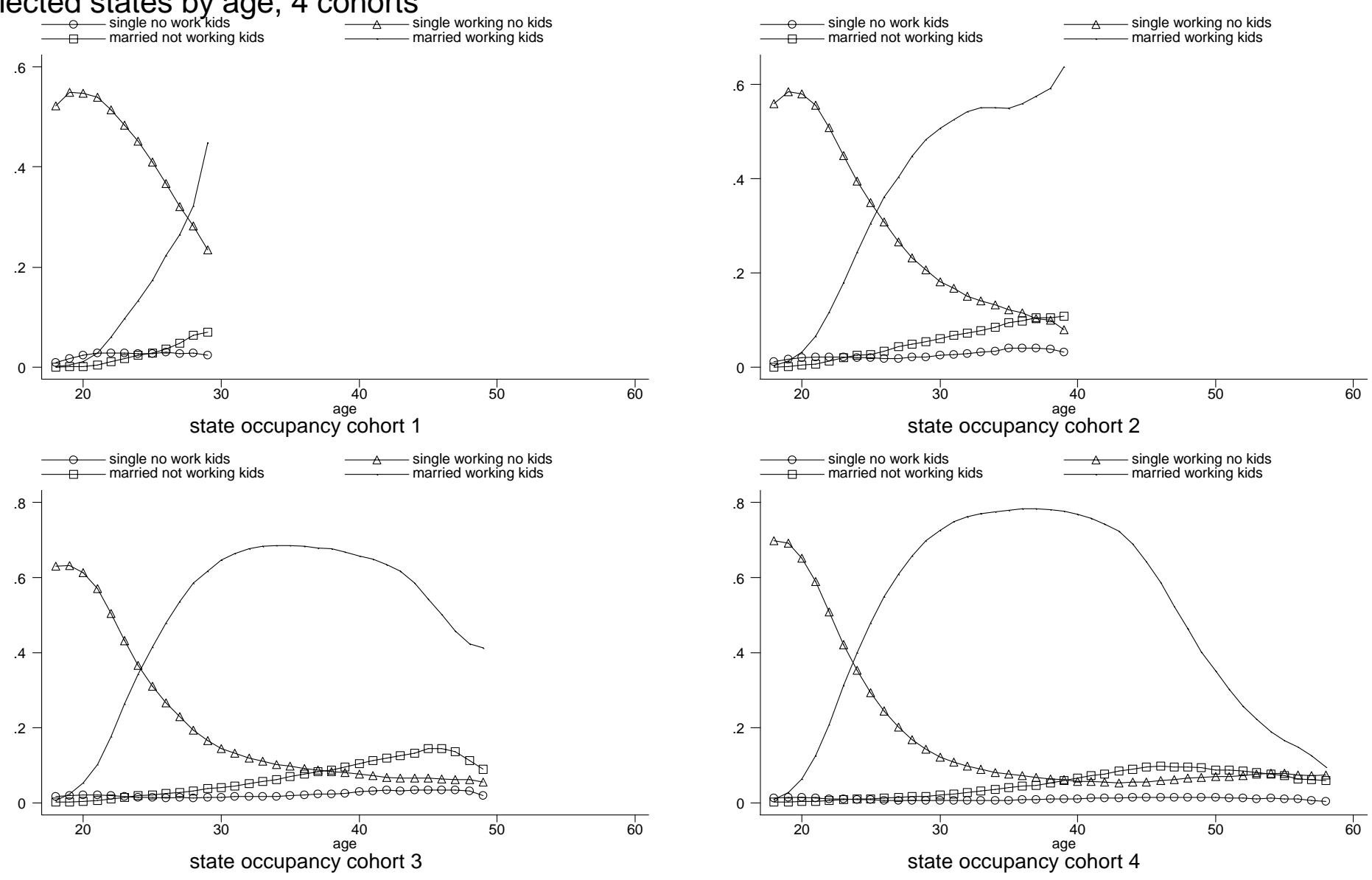
Figure 2: Distribution of selected states by age and cohort: baserun, men
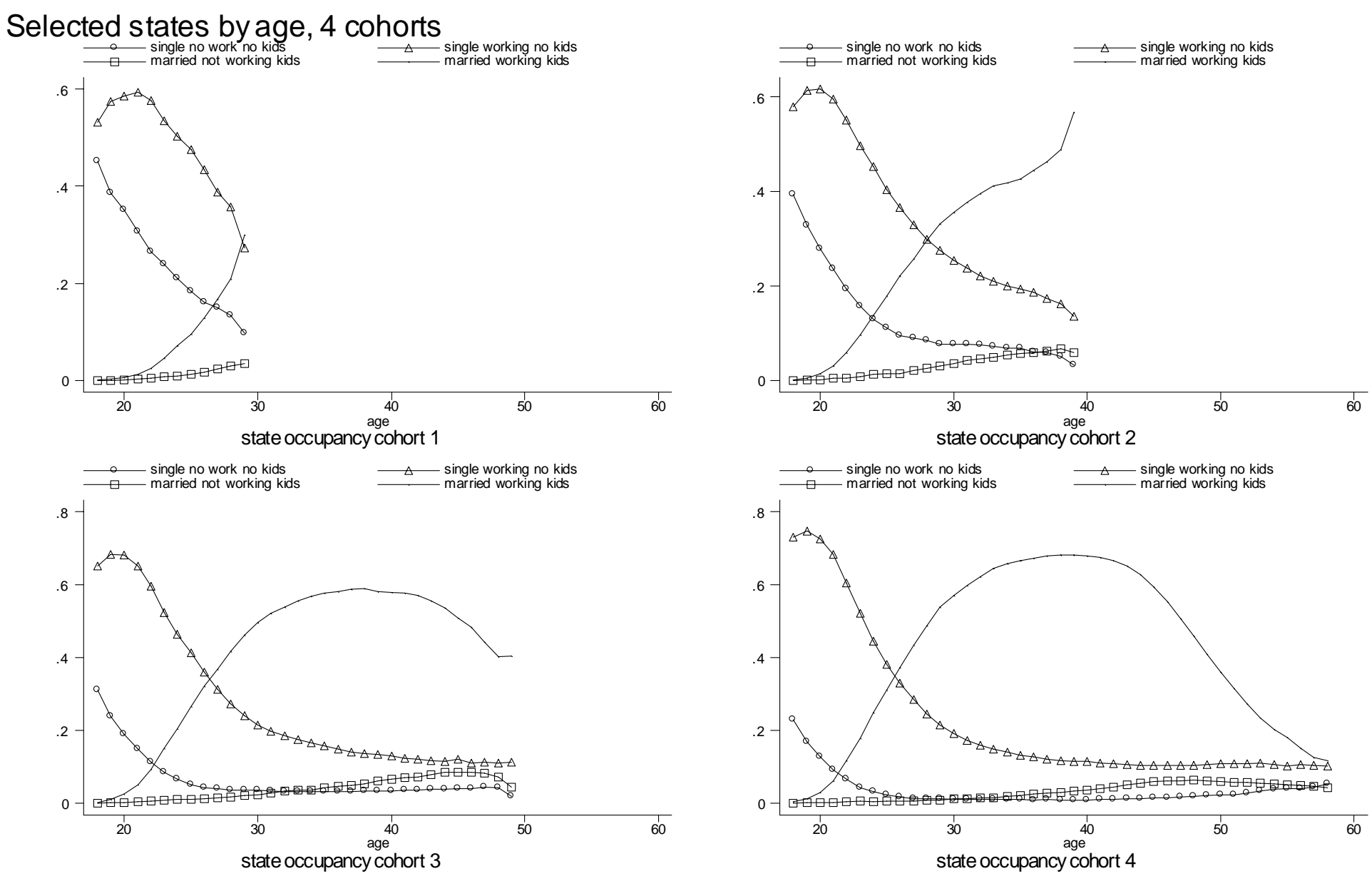
Table 1: Descriptive Statistics for Sample and Simulated Data

\begin{tabular}{|c|c|c|c|c|}
\hline & \multicolumn{2}{|c|}{ WOMEN } & \multicolumn{2}{|c|}{ MEN } \\
\hline & Sample & Simulated & Sample & Simulated \\
\hline Mean time until first birth & 13.57 & 13.87 & 16.46 & 16.84 \\
\hline Mean time until second birth & 4.36 & 4.95 & 4.62 & 5.42 \\
\hline Mean time until third birth & 9.15 & 9.59 & 10.48 & 10.61 \\
\hline Mean time until fourth birth & 8.98 & 11.07 & 9.75 & 12.29 \\
\hline proportion having at least one child & 0.68 & 0.68 & 0.58 & 0.59 \\
\hline proportion having at least two children & 0.76 & 0.75 & 0.73 & 0.72 \\
\hline proportion having at least three children & 0.39 & 0.40 & 0.34 & 0.36 \\
\hline proportion having at least four children & 0.27 & 0.25 & 0.28 & 0.25 \\
\hline Mean time until first union & 10.37 & 10.47 & 13.08 & 13.43 \\
\hline Mean time until second union & 5.26 & 5.50 & 4.10 & 4.57 \\
\hline proportion forming at least one union & 0.86 & 0.87 & 0.77 & 0.77 \\
\hline proportion forming 2nd union after dissolution & 0.59 & 0.57 & 0.60 & 0.61 \\
\hline Mean time until first union dissolution & 15.39 & 15.38 & 14.75 & 14.75 \\
\hline Mean time until second union dissolution & 8.67 & 9.20 & 7.63 & 7.98 \\
\hline proportion dissolving at least one union & 0.35 & 0.35 & 0.28 & 0.28 \\
\hline proportion dissolving 2nd union & 0.32 & 0.30 & 0.37 & 0.34 \\
\hline Mean time until first employment & 4.97 & 4.94 & 5.01 & 4.86 \\
\hline Mean time until second employment & 4.89 & 4.31 & 1.62 & 1.88 \\
\hline Mean time until third employment & 2.94 & 3.59 & 1.29 & 1.55 \\
\hline Mean time until fourth employment & 2.36 & 3.01 & 1.53 & 1.37 \\
\hline Mean time until fifth employment & 1.78 & 2.99 & 1.05 & 1.16 \\
\hline Mean time until sixth employment & 1.38 & 2.83 & 1.17 & 1.14 \\
\hline proportion finding employment at least once & 0.97 & 0.98 & 0.98 & 0.98 \\
\hline proportion finding employment after 1 st unemployment & 0.88 & 0.84 & 0.87 & 0.86 \\
\hline proportion finding employment after 2 nd unemployment & 0.81 & 0.79 & 0.86 & 0.83 \\
\hline proportion finding employment after 3rd unemployment & 0.78 & 0.78 & 0.82 & 0.83 \\
\hline proportion finding employment after 4th unemployment & 0.76 & 0.74 & 0.86 & 0.82 \\
\hline proportion finding employment after 5 th unemployment & 0.77 & 0.72 & 0.74 & 0.81 \\
\hline Mean time until first non-employment spell & 7.47 & 7.31 & 14.53 & 15.34 \\
\hline Mean time until second non-employment spell & 6.97 & 7.17 & 6.83 & 7.58 \\
\hline Mean time until third non-employment spell & 5.73 & 5.21 & 4.68 & 5.03 \\
\hline Mean time until fourth non-employment spell & 4.36 & 4.31 & 3.11 & 3.85 \\
\hline Mean time until fifth non-employment spell & 3.69 & 3.57 & 2.08 & 2.79 \\
\hline proportion becoming unemployed after 1st employment & 0.80 & 0.86 & 0.53 & 0.56 \\
\hline proportion becoming unemployed after 2 nd employment & 0.61 & 0.63 & 0.50 & 0.54 \\
\hline proportion becoming unemployed after 3rd employment & 0.55 & 0.64 & 0.54 & 0.58 \\
\hline proportion becoming unemployed after 4th employment & 0.51 & 0.64 & 0.52 & 0.60 \\
\hline proportion becoming unemployed after 5 th employment & 0.53 & 0.67 & 0.65 & 0.66 \\
\hline
\end{tabular}


Table 2a: Parameter Estimates - Fertility Transitions

\begin{tabular}{|c|c|c|c|c|}
\hline & Model 1 & Model 2 & Model 3 & Model 4 \\
\hline & $\begin{array}{l}\text { Women } \\
\text { no Het. }\end{array}$ & $\begin{array}{l}\text { Women } \\
\text { with Het. }\end{array}$ & $\begin{array}{c}\text { Men } \\
\text { no Het. }\end{array}$ & $\begin{array}{c}\text { Men } \\
\text { with Het. }\end{array}$ \\
\hline BIRTH ORDER 2 & $\begin{array}{c}-0.3508 * * * \\
(0.0902)\end{array}$ & $\begin{array}{c}-0.9432 * * * \\
(0.1221)\end{array}$ & $\begin{array}{c}-0.7775 * * * \\
(0.1243)\end{array}$ & $\begin{array}{c}-1.2704 * * * \\
(0.1672)\end{array}$ \\
\hline BIRTH ORDER 3 & $\begin{array}{c}-1.5484 * * * \\
(0.0995)\end{array}$ & $\begin{array}{c}-2.7509 * * * \\
(0.1444)\end{array}$ & $\begin{array}{c}-2.0363 * * * \\
(0.1352)\end{array}$ & $\begin{array}{c}-2.9772 * * * \\
(0.2044)\end{array}$ \\
\hline BIRTH ORDER $4,5 \& 6$ & $\begin{array}{c}-1.8406 * * * \\
(0.1219)\end{array}$ & $\begin{array}{c}-3.8723 * * * \\
(0.1888)\end{array}$ & $\begin{array}{c}-2.2318 * * * \\
(0.1596)\end{array}$ & $\begin{array}{c}-3.8089 * * * \\
(0.2559)\end{array}$ \\
\hline COHORT $1950-1960$ & $\begin{array}{l}-0.0139 \\
(0.0386)\end{array}$ & $\begin{array}{l}-0.0275 \\
(0.0636)\end{array}$ & $\begin{array}{l}-0.0074 \\
(0.0421)\end{array}$ & $\begin{array}{l}-0.0626 \\
(0.0689)\end{array}$ \\
\hline COHORT $1960-1970$ & $\begin{array}{c}-0.2396 * * * \\
(0.0432)\end{array}$ & $\begin{array}{c}-0.3909 * * * \\
(0.0686)\end{array}$ & $\begin{array}{c}-0.4068 * * * \\
(0.0550)\end{array}$ & $\begin{array}{c}-0.5677 \text { *** } \\
(0.0832)\end{array}$ \\
\hline COHORT $1970+$ & $\begin{array}{c}-0.7055 * * * \\
(0.0977)\end{array}$ & $\begin{array}{c}-0.9392 * * * \\
(0.1315)\end{array}$ & $\begin{array}{c}-0.6713 * * * \\
(0.1475)\end{array}$ & $\begin{array}{c}-0.8396 * * * \\
(0.1753)\end{array}$ \\
\hline \multirow[t]{2}{*}{$\begin{array}{l}\text { DID NOT LIVE WITH BOTH PARENTS AT } \\
14\end{array}$} & $0.1681 * * *$ & $0.2832 * * *$ & $0.1096 * *$ & $0.2260 * * *$ \\
\hline & $(0.0413)$ & $(0.0701)$ & $(0.0521)$ & $(0.0832)$ \\
\hline FATHER PROFESSIONAL OCC. & $\begin{array}{l}-0.0536 \\
(0.0445)\end{array}$ & $\begin{array}{c}-0.1409 * * \\
(0.0700)\end{array}$ & $\begin{array}{l}-0.0615 \\
(0.0477)\end{array}$ & $\begin{array}{l}-0.1082 \\
(0.0718)\end{array}$ \\
\hline MOTHER PROFESSIONAL OCC. & $\begin{array}{l}-0.0079 \\
(0.0556)\end{array}$ & $\begin{array}{l}-0.0407 \\
(0.0927)\end{array}$ & $\begin{array}{c}0.0616 \\
(0.0643)\end{array}$ & $\begin{array}{c}0.0380 \\
(0.0997)\end{array}$ \\
\hline NON-WHITE & $\begin{array}{c}0.1949 * * * \\
(0.0648)\end{array}$ & $\begin{array}{c}0.3133 * * * \\
(0.1170)\end{array}$ & $\begin{array}{c}0.3584 * * * \\
(0.0778)\end{array}$ & $\begin{array}{c}0.4530 * * * \\
(0.1346)\end{array}$ \\
\hline SUB O-LEVEL QUALIFICATIONS & $\begin{array}{c}-0.1322 * * \\
(0.0550)\end{array}$ & $\begin{array}{c}-0.3583 * * * \\
(0.0917)\end{array}$ & $\begin{array}{l}-0.0124 \\
(0.0709)\end{array}$ & $\begin{array}{c}0.0177 \\
(0.1108)\end{array}$ \\
\hline O-LEVELS OR EQUIVALENT & $\begin{array}{c}-0.2495 * * * \\
(0.0491)\end{array}$ & $\begin{array}{c}-0.6063 * * * \\
(0.0813)\end{array}$ & $\begin{array}{l}-0.1097 * \\
(0.0566)\end{array}$ & $\begin{array}{l}-0.1186 \\
(0.0885)\end{array}$ \\
\hline A-LEVELS OR EQUIVALENT & $\begin{array}{c}-0.3109 * * * \\
(0.0469)\end{array}$ & $\begin{array}{c}-0.7259 * * * \\
(0.0804)\end{array}$ & $\begin{array}{c}-0.1612 * * * \\
(0.0505)\end{array}$ & $\begin{array}{c}-0.2454 * * * \\
(0.0799)\end{array}$ \\
\hline HIGHER QUALIFICATION & $\begin{array}{c}-0.3914 * * * \\
(0.0573)\end{array}$ & $\begin{array}{c}-0.9509 * * * \\
(0.0998)\end{array}$ & $\begin{array}{c}-0.2205 * * * \\
(0.0667)\end{array}$ & $\begin{array}{c}-0.4605 * * * \\
(0.1071)\end{array}$ \\
\hline MARRIED OR COHABITING & $\begin{array}{c}1.8192 * * * \\
(0.0500)\end{array}$ & $\begin{array}{c}1.7611 * * * \\
(0.0598)\end{array}$ & $\begin{array}{c}2.1565 * * * \\
(0.0600)\end{array}$ & $\begin{array}{c}2.0787 * * * \\
(0.0782)\end{array}$ \\
\hline WORKING (INCL. PART TIME) & $\begin{array}{c}-0.2088 * * * \\
(0.0434)\end{array}$ & $\begin{array}{c}-0.1885 * * * \\
(0.0505)\end{array}$ & $\begin{array}{c}0.3573 * * * \\
(0.0751)\end{array}$ & $\begin{array}{c}0.3832 * * * \\
(0.0893)\end{array}$ \\
\hline
\end{tabular}


Table 2b: Parameter Estimates - Union Transitions

\begin{tabular}{|c|c|c|c|c|}
\hline & $\begin{array}{c}\text { Model } 1 \\
\text { Women } \\
\text { no Het. }\end{array}$ & $\begin{array}{c}\text { Model } 2 \\
\text { Women } \\
\text { with Het. }\end{array}$ & $\begin{array}{c}\text { Model 3 } \\
\text { Men } \\
\text { no Het. }\end{array}$ & $\begin{array}{c}\text { Model } 4 \\
\text { Men } \\
\text { with Het. }\end{array}$ \\
\hline MARRIAGE ORDER 2 & $\begin{array}{c}-0.5054 \text { *** } \\
(0.1670)\end{array}$ & $\begin{array}{c}-1.3474 * * * \\
(0.2238)\end{array}$ & $\begin{array}{l}-0.0371 \\
(0.2321)\end{array}$ & $\begin{array}{l}-0.4008 \\
(0.2981)\end{array}$ \\
\hline MARRIAGE ORDER 3 OR 4 & $\begin{array}{c}-0.3554 * \\
(0.2097)\end{array}$ & $\begin{array}{c}-1.8064 * * * \\
(0.2945)\end{array}$ & $\begin{array}{c}0.0208 \\
(0.2486)\end{array}$ & $\begin{array}{c}-0.7455 * * \\
(0.3662)\end{array}$ \\
\hline COHORT $1950-1960$ & $\begin{array}{c}0.0802 \\
(0.0507)\end{array}$ & $\begin{array}{c}0.1907 * * \\
(0.0772)\end{array}$ & $\begin{array}{c}-0.0862 \\
(0.0549)\end{array}$ & $\begin{array}{l}-0.0640 \\
(0.0777)\end{array}$ \\
\hline COHORT $1960-1970$ & $\begin{array}{c}-0.1512 * * * \\
(0.0545)\end{array}$ & $\begin{array}{c}-0.1526 * * \\
(0.0778)\end{array}$ & $\begin{array}{c}-0.1154 * \\
(0.0593)\end{array}$ & $\begin{array}{l}-0.1149 \\
(0.0827)\end{array}$ \\
\hline COHORT $1970+$ & $\begin{array}{c}-0.4459 * * * \\
(0.0825)\end{array}$ & $\begin{array}{c}-0.5513 * * * \\
(0.1079)\end{array}$ & $\begin{array}{c}-0.6798 * * * \\
(0.0998)\end{array}$ & $\begin{array}{c}-0.7884 \text { *** } \\
(0.1226)\end{array}$ \\
\hline $\begin{array}{l}\text { DID NOT LIVE WITH BOTH PARENTS } \\
\text { AT } 14\end{array}$ & $0.1748 * * *$ & $0.2767 * * *$ & $0.1533 * * *$ & $0.2455 * * *$ \\
\hline & $(0.0534)$ & $(0.0777)$ & $(0.0588)$ & $(0.0856)$ \\
\hline FATHER PROFESSIONAL OCC. & $\begin{array}{c}0.0283 \\
(0.0510)\end{array}$ & $\begin{array}{l}-0.0070 \\
(0.0734)\end{array}$ & $\begin{array}{l}-0.0183 \\
(0.0525)\end{array}$ & $\begin{array}{l}-0.0381 \\
(0.0736)\end{array}$ \\
\hline MOTHER PROFESSIONAL OCC. & $\begin{array}{l}-0.0061 \\
(0.0658)\end{array}$ & $\begin{array}{l}-0.0278 \\
(0.0956)\end{array}$ & $\begin{array}{c}-0.0422 \\
(0.0795)\end{array}$ & $\begin{array}{l}-0.0962 \\
(0.1068)\end{array}$ \\
\hline NON-WHITE & $\begin{array}{c}-0.3778 * * * \\
(0.0914)\end{array}$ & $\begin{array}{c}-0.4329 * * * \\
(0.1217)\end{array}$ & $\begin{array}{c}-0.3780 * * * \\
(0.1107)\end{array}$ & $\begin{array}{c}-0.4978 * * * \\
(0.1474)\end{array}$ \\
\hline SUB O-LEVEL QUALIFICATIONS & $\begin{array}{c}-0.1557 * * \\
(0.0760)\end{array}$ & $\begin{array}{c}-0.2824 * * \\
(0.1113)\end{array}$ & $\begin{array}{c}0.1175 \\
(0.0931)\end{array}$ & $\begin{array}{c}0.1596 \\
(0.1242)\end{array}$ \\
\hline O-LEVELS OR EQUIVALENT & $\begin{array}{c}-0.1321 * * \\
(0.0605)\end{array}$ & $\begin{array}{c}-0.2774 * * * \\
(0.0877)\end{array}$ & $\begin{array}{c}0.2809 * * * \\
(0.0773)\end{array}$ & $\begin{array}{c}0.3215 * * * \\
(0.1049)\end{array}$ \\
\hline A-LEVELS OR EQUIVALENT & $\begin{array}{c}-0.1041 * \\
(0.0600)\end{array}$ & $\begin{array}{c}-0.2843 * * * \\
(0.0873)\end{array}$ & $\begin{array}{c}0.2334 * * * \\
(0.0638)\end{array}$ & $\begin{array}{c}0.2503 * * * \\
(0.0884)\end{array}$ \\
\hline HIGHER QUALIFICATION & $\begin{array}{c}-0.2708 * * * \\
(0.0709)\end{array}$ & $\begin{array}{c}-0.6370 * * * \\
(0.1063)\end{array}$ & $\begin{array}{c}0.1844 * * \\
(0.0787)\end{array}$ & $\begin{array}{c}0.0548 \\
(0.1073)\end{array}$ \\
\hline FIRST BIRTH & $\begin{array}{c}0.8989 * * * \\
(0.0513)\end{array}$ & $\begin{array}{c}0.9186 * * * \\
(0.0661)\end{array}$ & $\begin{array}{c}1.1275 * * * \\
(0.0555)\end{array}$ & $\begin{array}{c}1.2512 \text { **** } \\
(0.0849)\end{array}$ \\
\hline SECOND BIRTH & $\begin{array}{c}-0.3181 * * * \\
(0.0894)\end{array}$ & $\begin{array}{c}-0.6107 * * * \\
(0.1019)\end{array}$ & $\begin{array}{c}-0.5117 * * * \\
(0.1061)\end{array}$ & $\begin{array}{c}-0.9079 * * * \\
(0.1276)\end{array}$ \\
\hline THIRD BIRTH & $\begin{array}{l}-0.0460 \\
(0.1388)\end{array}$ & $\begin{array}{l}-0.2261 \\
(0.1493)\end{array}$ & $\begin{array}{c}-0.0057 \\
(0.2085)\end{array}$ & $\begin{array}{l}-0.0149 \\
(0.2388)\end{array}$ \\
\hline FOURTH BIRTH & $\begin{array}{c}0.2348 \\
(0.2461)\end{array}$ & $\begin{array}{l}-0.0552 \\
(0.2712)\end{array}$ & $\begin{array}{c}0.2652 \\
(0.3646)\end{array}$ & $\begin{array}{l}-0.2928 \\
(0.4548)\end{array}$ \\
\hline FIFTH \& SIXTH BIRTH & $\begin{array}{c}0.1028 \\
(0.3530)\end{array}$ & $\begin{array}{c}-0.0174 \\
(0.3801)\end{array}$ & $\begin{array}{l}-0.5605 \\
(0.6545)\end{array}$ & $\begin{array}{l}-0.8058 \\
(0.6903)\end{array}$ \\
\hline WORKING (INCL. PART TIME) & $\begin{array}{c}0.6683 * * * \\
(0.0544)\end{array}$ & $\begin{array}{c}0.5405 * * * \\
(0.0633)\end{array}$ & $\begin{array}{c}0.9027 * * * \\
(0.0753)\end{array}$ & $\begin{array}{c}0.7354 * * * \\
(0.0880)\end{array}$ \\
\hline
\end{tabular}


Table 2c: Parameter Estimates - Dissolution Transitions

\begin{tabular}{|c|c|c|c|c|}
\hline & $\begin{array}{l}\text { Model } 1 \\
\text { Women } \\
\text { no Het. }\end{array}$ & $\begin{array}{c}\text { Model } 2 \\
\text { Women } \\
\text { with Het. } \\
\end{array}$ & $\begin{array}{c}\text { Model } 3 \\
\text { Men } \\
\text { no Het. }\end{array}$ & $\begin{array}{c}\text { Model } 4 \\
\text { Men } \\
\text { with Het. }\end{array}$ \\
\hline DISSOLUTION ORDER 2 & $\begin{array}{c}0.4748 * * * \\
(0.1090)\end{array}$ & $\begin{array}{l}-0.3074 \\
(0.3061)\end{array}$ & $(0.1160)$ & $(0.2895)$ \\
\hline DISSOLUTION ORDER 3 OR 4 & $\begin{array}{c}1.3898 * * * \\
(0.2293)\end{array}$ & $\begin{array}{l}-0.0294 \\
(0.5252)\end{array}$ & $\begin{array}{c}1.1459 * * * \\
(0.1956)\end{array}$ & $\begin{array}{c}0.0841 \\
(0.5049)\end{array}$ \\
\hline COHORT $1950-1960$ & $\begin{array}{c}0.5094 * * * \\
(0.0974)\end{array}$ & $\begin{array}{c}0.6332 * * * \\
(0.1256)\end{array}$ & $\begin{array}{c}0.5538 * * * \\
(0.1173)\end{array}$ & $\begin{array}{c}0.6654 * * * \\
(0.1401)\end{array}$ \\
\hline COHORT $1960-1970$ & $\begin{array}{c}0.9810 * * * \\
(0.1142)\end{array}$ & $\begin{array}{c}1.1336 * * * \\
(0.1478)\end{array}$ & $\begin{array}{c}1.1089 * * * \\
(0.1378)\end{array}$ & $\begin{array}{c}1.3202 * * * \\
(0.1815)\end{array}$ \\
\hline COHORT $1970+$ & $\begin{array}{c}1.6629 * * * \\
(0.1645)\end{array}$ & $\begin{array}{c}1.8736 * * * \\
(0.2204)\end{array}$ & $\begin{array}{c}1.4646 * * * \\
(0.2217)\end{array}$ & $\begin{array}{c}1.6712 * * * \\
(0.2724)\end{array}$ \\
\hline DID NOT LIVE WITH BOTH PARENTS AT 14 & $\begin{array}{c}0.3991 * * * \\
(0.0878)\end{array}$ & $\begin{array}{c}0.5218 * * * \\
(0.1189)\end{array}$ & $\begin{array}{c}0.2825 * * * \\
(0.1076)\end{array}$ & $\begin{array}{c}0.3572 * * * \\
(0.1322)\end{array}$ \\
\hline FATHER PROFESSIONAL OCC. & $\begin{array}{c}0.1213 \\
(0.0865)\end{array}$ & $\begin{array}{c}0.1125 \\
(0.1048)\end{array}$ & $\begin{array}{c}0.0818 \\
(0.1010)\end{array}$ & $\begin{array}{c}0.0740 \\
(0.1193)\end{array}$ \\
\hline MOTHER PROFESSIONAL OCC. & $\begin{array}{c}0.0125 \\
(0.1189)\end{array}$ & $\begin{array}{c}0.0306 \\
(0.1401)\end{array}$ & $\begin{array}{c}0.0747 \\
(0.1354)\end{array}$ & $\begin{array}{c}0.0788 \\
(0.1564)\end{array}$ \\
\hline NON-WHITE & $\begin{array}{c}0.1245 \\
(0.1532)\end{array}$ & $\begin{array}{c}0.1260 \\
(0.1848)\end{array}$ & $\begin{array}{l}-0.0283 \\
(0.2449)\end{array}$ & $\begin{array}{c}-0.0644 \\
(0.2763)\end{array}$ \\
\hline SUB O-LEVEL QUALIFICATIONS & $\begin{array}{l}-0.0779 \\
(0.1327)\end{array}$ & $\begin{array}{l}-0.1898 \\
(0.1614)\end{array}$ & $\begin{array}{c}0.1113 \\
(0.1967)\end{array}$ & $\begin{array}{c}0.1501 \\
(0.2244)\end{array}$ \\
\hline O-LEVELS OR EQUIVALENT & $\begin{array}{l}-0.0622 \\
(0.1089)\end{array}$ & $\begin{array}{l}-0.1865 \\
(0.1367)\end{array}$ & $\begin{array}{c}0.1148 \\
(0.1511)\end{array}$ & $\begin{array}{c}0.1194 \\
(0.1775)\end{array}$ \\
\hline A-LEVELS OR EQUIVALENT & $\begin{array}{c}0.0997 \\
(0.1042)\end{array}$ & $\begin{array}{l}-0.0031 \\
(0.1308)\end{array}$ & $\begin{array}{c}0.1604 \\
(0.1337)\end{array}$ & $\begin{array}{c}0.1431 \\
(0.1541)\end{array}$ \\
\hline HIGHER QUALIFICATION & $\begin{array}{c}0.0519 \\
(0.1197)\end{array}$ & $\begin{array}{l}-0.0828 \\
(0.1526)\end{array}$ & $\begin{array}{c}0.1781 \\
(0.1516)\end{array}$ & $\begin{array}{c}0.1443 \\
(0.1752)\end{array}$ \\
\hline FIRST BIRTH & $\begin{array}{c}-0.2754 * * * \\
(0.1020)\end{array}$ & $\begin{array}{c}-0.2409 * * \\
(0.1114)\end{array}$ & $\begin{array}{c}-0.4756 \text { *** } \\
(0.1116)\end{array}$ & $\begin{array}{c}-0.5765 * * * \\
(0.1219)\end{array}$ \\
\hline SECOND BIRTH & $\begin{array}{l}-0.1372 \\
(0.1031)\end{array}$ & $\begin{array}{c}-0.2831 * * \\
(0.1190)\end{array}$ & $\begin{array}{c}-0.2823 * * \\
(0.1252)\end{array}$ & $\begin{array}{c}-0.3995 * * * \\
(0.1451)\end{array}$ \\
\hline THIRD BIRTH & $\begin{array}{c}0.0847 \\
(0.1184)\end{array}$ & $\begin{array}{c}0.0041 \\
(0.1324)\end{array}$ & $\begin{array}{l}-0.2395 \\
(0.1958)\end{array}$ & $\begin{array}{l}-0.3401 \\
(0.2157)\end{array}$ \\
\hline FOURTH, FIFTH \& SIXTH BIRTH & $\begin{array}{l}0.3221 * \\
(0.1747)\end{array}$ & $\begin{array}{c}0.2017 \\
(0.2044)\end{array}$ & $\begin{array}{l}0.4863 * \\
(0.2593)\end{array}$ & $\begin{array}{c}0.2630 \\
(0.2954)\end{array}$ \\
\hline WORKING (INCL. PART TIME) & $\begin{array}{c}0.0538 \\
(0.0775)\end{array}$ & $\begin{array}{c}0.2215 * * \\
(0.0889)\end{array}$ & $\begin{array}{l}-0.1878 \\
(0.1151)\end{array}$ & $\begin{array}{c}0.0831 \\
(0.1352)\end{array}$ \\
\hline
\end{tabular}


Table 2d: Parameter Estimates - Employment Transitions

\begin{tabular}{|c|c|c|c|c|}
\hline & $\begin{array}{l}\text { Model } 1 \\
\text { Women } \\
\text { no Het. }\end{array}$ & $\begin{array}{c}\text { Model } 2 \\
\text { Women } \\
\text { with Het. }\end{array}$ & $\begin{array}{c}\text { Model 3 } \\
\text { Men } \\
\text { no Het. }\end{array}$ & $\begin{array}{c}\text { Model } 4 \\
\text { Men } \\
\text { with Het. }\end{array}$ \\
\hline EMPLOYMENT ORDER 2 & $\begin{array}{c}-0.4154 * * * \\
(0.0629)\end{array}$ & $\begin{array}{c}-0.4763 \text { *** } \\
(0.0761)\end{array}$ & $\begin{array}{c}-0.9261 * * * \\
(0.1082)\end{array}$ & $\begin{array}{c}-0.9114 * * * \\
(0.1240)\end{array}$ \\
\hline EMPLOYMENT ORDER 3 & $\begin{array}{l}-0.1064 \\
(0.0772)\end{array}$ & $\begin{array}{c}-0.1767 * \\
(0.0993)\end{array}$ & $\begin{array}{c}-0.8955 * * * \\
(0.1188)\end{array}$ & $\begin{array}{c}-0.8783 \text { *** } \\
(0.1454)\end{array}$ \\
\hline EMPLOYMENT ORDER 4 OR HIGHER & $\begin{array}{c}0.1354 \\
(0.0866)\end{array}$ & $\begin{array}{c}0.0151 \\
(0.1190)\end{array}$ & $\begin{array}{c}-0.8886 \text { *** } \\
(0.1235)\end{array}$ & $\begin{array}{c}-0.9520 * * * \\
(0.1544)\end{array}$ \\
\hline COHORT $1950-1960$ & $\begin{array}{c}0.1786 * * * \\
(0.0358)\end{array}$ & $\begin{array}{c}0.1779 * * * \\
(0.0390)\end{array}$ & $\begin{array}{c}-0.1375 * * * \\
(0.0396)\end{array}$ & $\begin{array}{c}-0.1940 * * * \\
(0.0508)\end{array}$ \\
\hline COHORT $1960-1970$ & $\begin{array}{c}0.0521 \\
(0.0409)\end{array}$ & $\begin{array}{c}0.0223 \\
(0.0445)\end{array}$ & $\begin{array}{c}-0.2858 * * * \\
(0.0476)\end{array}$ & $\begin{array}{c}-0.3944 * * * \\
(0.0608)\end{array}$ \\
\hline COHORT $1970+$ & $\begin{array}{l}-0.0239 \\
(0.0599)\end{array}$ & $\begin{array}{l}-0.0643 \\
(0.0635)\end{array}$ & $\begin{array}{c}-0.2555 * * * \\
(0.0549)\end{array}$ & $\begin{array}{c}-0.3791 * * * \\
(0.0694)\end{array}$ \\
\hline DID NOT LIVE WITH BOTH PARENTS AT 14 & $\begin{array}{c}0.0589 \\
(0.0371)\end{array}$ & $\begin{array}{c}0.0634 \\
(0.0410)\end{array}$ & $\begin{array}{c}0.0308 \\
(0.0457)\end{array}$ & $\begin{array}{c}0.0177 \\
(0.0582)\end{array}$ \\
\hline FATHER PROFESSIONAL OCC. & $\begin{array}{c}-0.0902 * * * \\
(0.0349)\end{array}$ & $\begin{array}{c}-0.1040 * * * \\
(0.0379)\end{array}$ & $\begin{array}{c}-0.1051 * * \\
(0.0425)\end{array}$ & $\begin{array}{c}-0.1384 * * * \\
(0.0532)\end{array}$ \\
\hline MOTHER PROFESSIONAL OCC. & $\begin{array}{c}-0.1035 * * \\
(0.0465)\end{array}$ & $\begin{array}{c}-0.1066 * * \\
(0.0516)\end{array}$ & $\begin{array}{l}-0.0182 \\
(0.0599)\end{array}$ & $\begin{array}{l}-0.0313 \\
(0.0744)\end{array}$ \\
\hline NON-WHITE & $\begin{array}{c}-0.4207 * * * \\
(0.0637)\end{array}$ & $\begin{array}{c}-0.4454 * * * \\
(0.0702)\end{array}$ & $\begin{array}{c}-0.4388 * * * \\
(0.0799)\end{array}$ & $\begin{array}{c}-0.5195 * * * \\
(0.0967)\end{array}$ \\
\hline SUB O-LEVEL QUALIFICATIONS & $\begin{array}{c}0.1622 * * * \\
(0.0493)\end{array}$ & $\begin{array}{c}0.1536 * * * \\
(0.0550)\end{array}$ & $\begin{array}{c}0.0224 \\
(0.0607)\end{array}$ & $\begin{array}{c}0.0136 \\
(0.0796)\end{array}$ \\
\hline O-LEVELS OR EQUIVALENT & $\begin{array}{c}0.2111 * * * \\
(0.0434)\end{array}$ & $\begin{array}{c}0.1910 * * * \\
(0.0491)\end{array}$ & $\begin{array}{l}0.0927 * \\
(0.0478)\end{array}$ & $\begin{array}{c}0.0790 \\
(0.0646)\end{array}$ \\
\hline A-LEVELS OR EQUIVALENT & $\begin{array}{c}0.1009 * * \\
(0.0430)\end{array}$ & $\begin{array}{c}0.0719 \\
(0.0472)\end{array}$ & $\begin{array}{l}-0.0205 \\
(0.0431)\end{array}$ & $\begin{array}{c}-0.0908 \\
(0.0564)\end{array}$ \\
\hline HIGHER QUALIFICATION & $\begin{array}{c}-0.2708 * * * \\
(0.0489)\end{array}$ & $\begin{array}{c}-0.3384 * * * \\
(0.0533)\end{array}$ & $\begin{array}{c}-0.6807 \text { *** } \\
(0.0689)\end{array}$ & $\begin{array}{c}-0.9084 * * * \\
(0.0862)\end{array}$ \\
\hline FIRST BIRTH & $\begin{array}{c}-0.8019 * * * \\
(0.0513)\end{array}$ & $\begin{array}{c}-0.8402 * * * \\
(0.0529)\end{array}$ & $\begin{array}{c}-0.1944 * * * \\
(0.0715)\end{array}$ & $\begin{array}{c}-0.2186 * * * \\
(0.0783)\end{array}$ \\
\hline SECOND BIRTH & $\begin{array}{l}0.0931 * \\
(0.0542)\end{array}$ & $\begin{array}{c}0.0355 \\
(0.0554)\end{array}$ & $\begin{array}{l}-0.1068 \\
(0.0770)\end{array}$ & $\begin{array}{c}-0.1927 * * \\
(0.0835)\end{array}$ \\
\hline THIRD BIRTH & $\begin{array}{c}-0.1884 * * * \\
(0.0626)\end{array}$ & $\begin{array}{c}-0.2550 * * * \\
(0.0652)\end{array}$ & $\begin{array}{c}0.0652 \\
(0.0958)\end{array}$ & $\begin{array}{l}-0.0100 \\
(0.1041)\end{array}$ \\
\hline FOURTH BIRTH & $\begin{array}{c}-0.2446 * * \\
(0.1063)\end{array}$ & $\begin{array}{c}-0.3277 \text { *** } \\
(0.1119)\end{array}$ & $\begin{array}{c}-0.5409 \text { *** } \\
(0.1497)\end{array}$ & $\begin{array}{c}-0.6219 * * * \\
(0.1547)\end{array}$ \\
\hline FIFTH \& SIXTH BIRTH & $\begin{array}{c}-0.4801 * \\
(0.2451)\end{array}$ & $\begin{array}{c}-0.5858 * * \\
(0.2462)\end{array}$ & $\begin{array}{l}-0.3454 \\
(0.4283)\end{array}$ & $\begin{array}{c}-0.4822 \\
(0.4064)\end{array}$ \\
\hline MARRIED OR COHABITING & $\begin{array}{c}-0.1758 * * * \\
(0.0399)\end{array}$ & $\begin{array}{c}-0.2875 * * * \\
(0.0466)\end{array}$ & $\begin{array}{c}0.2446 * * * \\
(0.0526)\end{array}$ & $\begin{array}{r}0.0539 \\
(0.0659) \\
\end{array}$ \\
\hline
\end{tabular}


Table 2e: Parameter Estimates - Non-Employment Transitions

\begin{tabular}{|c|c|c|c|c|}
\hline & $\begin{array}{l}\text { Model } 1 \\
\text { Women } \\
\text { no Het. }\end{array}$ & $\begin{array}{c}\text { Model } 2 \\
\text { Women } \\
\text { with Het. }\end{array}$ & $\begin{array}{c}\text { Model } 3 \\
\text { Men } \\
\text { no Het. }\end{array}$ & $\begin{array}{c}\text { Model } 4 \\
\text { Men } \\
\text { with Het. }\end{array}$ \\
\hline UNEMPLYMENT ORDER 2 & $\begin{array}{c}-0.8023 * * * \\
(0.0473)\end{array}$ & $\begin{array}{c}-1.2456 * * * \\
(0.0773)\end{array}$ & $\begin{array}{c}0.3006 * * * \\
(0.0602)\end{array}$ & $\begin{array}{l}-0.1405 \\
(0.1211)\end{array}$ \\
\hline NON-EMPLOYMENT ORDER 3 & $\begin{array}{c}-0.5696 * * * \\
(0.0617)\end{array}$ & $\begin{array}{c}-1.3764 * * * \\
(0.1106)\end{array}$ & $\begin{array}{c}0.5834 * * * \\
(0.0830)\end{array}$ & $\begin{array}{l}-0.2159 \\
(0.1854)\end{array}$ \\
\hline \multirow[t]{2}{*}{$\begin{array}{l}\text { NON-EMPLOYMENT ORDER } 4 \text { OR } \\
\text { HIGHER }\end{array}$} & $-0.2242 * * *$ & $-1.4982 * * *$ & $0.9133 * * *$ & -0.3358 \\
\hline & $(0.0714)$ & $(0.1442)$ & $(0.0962)$ & $(0.2419)$ \\
\hline COHORT 1950 - 1960 & $\begin{array}{c}0.1053 * * * \\
(0.0396)\end{array}$ & $\begin{array}{c}0.2001 * * \\
(0.0808)\end{array}$ & $\begin{array}{c}0.5220 * * * \\
(0.0684)\end{array}$ & $\begin{array}{c}0.6976 * * * \\
(0.0957)\end{array}$ \\
\hline COHORT 1960 - 1970 & $\begin{array}{c}0.3368 * * * \\
(0.0451)\end{array}$ & $\begin{array}{c}0.4847 \text { *** } \\
(0.0831)\end{array}$ & $\begin{array}{c}1.1103 * * * \\
(0.0779)\end{array}$ & $\begin{array}{c}1.4182 * * * \\
(0.1151)\end{array}$ \\
\hline COHORT $1970+$ & $\begin{array}{c}0.9161 \text { *** } \\
(0.0622)\end{array}$ & $\begin{array}{c}1.3409 * * * \\
(0.1057)\end{array}$ & $\begin{array}{c}1.7138 * * * \\
(0.0940)\end{array}$ & $\begin{array}{c}2.2532 * * * \\
(0.1440)\end{array}$ \\
\hline \multirow[t]{2}{*}{$\begin{array}{l}\text { DID NOT LIVE WITH BOTH PARENTS AT } \\
14\end{array}$} & $0.1356 * * *$ & $0.1886 * *$ & 0.0130 & 0.0494 \\
\hline & $(0.0425)$ & $(0.0782)$ & $(0.0619)$ & $(0.0874)$ \\
\hline FATHER PROFESSIONAL OCC. & $\begin{array}{c}-0.0338 \\
(0.0371)\end{array}$ & $\begin{array}{l}-0.0935 \\
(0.0719)\end{array}$ & $\begin{array}{c}-0.1525 * * \\
(0.0613)\end{array}$ & $\begin{array}{c}-0.1997 * * \\
(0.0835)\end{array}$ \\
\hline MOTHER PROFESSIONAL OCC. & $\begin{array}{c}-0.1096 * * \\
(0.0451)\end{array}$ & $\begin{array}{l}-0.1494 \\
(0.0939)\end{array}$ & $\begin{array}{l}-0.0230 \\
(0.0832)\end{array}$ & $\begin{array}{l}-0.0103 \\
(0.1112)\end{array}$ \\
\hline NON-WHITE & $\begin{array}{c}0.0740 \\
(0.0665)\end{array}$ & $\begin{array}{c}0.1354 \\
(0.1271)\end{array}$ & $\begin{array}{c}0.0799 \\
(0.1197)\end{array}$ & $\begin{array}{c}0.1259 \\
(0.1536)\end{array}$ \\
\hline SUB O-LEVEL QUALIFICATIONS & $\begin{array}{l}-0.0850 \\
(0.0539)\end{array}$ & $\begin{array}{c}-0.2330 * * \\
(0.1093)\end{array}$ & $\begin{array}{c}-0.2373 * * \\
(0.0937)\end{array}$ & $\begin{array}{c}-0.2912 * * \\
(0.1376)\end{array}$ \\
\hline O-LEVELS OR EQUIVALENT & $\begin{array}{c}-0.3297 * * * \\
(0.0505)\end{array}$ & $\begin{array}{c}-0.6139 * * * \\
(0.0976)\end{array}$ & $\begin{array}{c}-0.3451 * * * \\
(0.0730)\end{array}$ & $\begin{array}{c}-0.4298 * * * \\
(0.1093)\end{array}$ \\
\hline A-LEVELS OR EQUIVALENT & $\begin{array}{c}-0.2411 * * * \\
(0.0458)\end{array}$ & $\begin{array}{c}-0.4706 * * * \\
(0.0911)\end{array}$ & $\begin{array}{c}-0.3006 \text { *** } \\
(0.0612)\end{array}$ & $\begin{array}{c}-0.3978 \text { *** } \\
(0.0970)\end{array}$ \\
\hline HIGHER QUALIFICATION & $\begin{array}{l}-0.0564 \\
(0.0508)\end{array}$ & $\begin{array}{c}-0.3115 * * * \\
(0.1012)\end{array}$ & $\begin{array}{c}-0.1818 * * \\
(0.0895)\end{array}$ & $\begin{array}{c}-0.2671 * * \\
(0.1339)\end{array}$ \\
\hline FIRST BIRTH & $\begin{array}{c}1.8999 * * * \\
(0.0386)\end{array}$ & $\begin{array}{c}2.0790 * * * \\
(0.0512)\end{array}$ & $\begin{array}{c}0.0491 \\
(0.0759)\end{array}$ & $\begin{array}{l}-0.0181 \\
(0.0826)\end{array}$ \\
\hline SECOND BIRTH & $\begin{array}{c}-0.8534 \text { *** } \\
(0.0492)\end{array}$ & $\begin{array}{c}-1.0061 * * * \\
(0.0564)\end{array}$ & $\begin{array}{l}-0.0155 \\
(0.0833)\end{array}$ & $\begin{array}{l}-0.0155 \\
(0.0944)\end{array}$ \\
\hline THIRD BIRTH & $\begin{array}{c}-0.0055 \\
(0.0702)\end{array}$ & $\begin{array}{c}-0.2559 * * * \\
(0.0810)\end{array}$ & $\begin{array}{c}0.0832 \\
(0.1018)\end{array}$ & $\begin{array}{c}0.0457 \\
(0.1183)\end{array}$ \\
\hline FOURTH BIRTH & $\begin{array}{c}0.0979 \\
(0.1027)\end{array}$ & $\begin{array}{c}-0.0731 \\
(0.1268)\end{array}$ & $\begin{array}{c}0.3827 * * \\
(0.1713)\end{array}$ & $\begin{array}{c}0.3016 \\
(0.2012)\end{array}$ \\
\hline FIFTH \& SIXTH BIRTH & $\begin{array}{c}0.4543 * * \\
(0.2146)\end{array}$ & $\begin{array}{c}0.3840 \\
(0.2553)\end{array}$ & $\begin{array}{c}0.4288 \\
(0.3277)\end{array}$ & $\begin{array}{c}0.4655 \\
(0.4355)\end{array}$ \\
\hline MARRIED OR COHABITING & $\begin{array}{c}0.6255 * * * \\
(0.0415) \\
\end{array}$ & $\begin{array}{c}0.8027 * * * \\
(0.0510) \\
\end{array}$ & $\begin{array}{c}-0.1931 * * * \\
(0.0624) \\
\end{array}$ & $\begin{array}{l}-0.0787 \\
(0.0747) \\
\end{array}$ \\
\hline
\end{tabular}


Table 3a: Baseline Duration and Age Parameters - Fertility Transitions

\begin{tabular}{|c|c|c|c|c|}
\hline & Model 1 & Model 2 & Model 3 & Model 4 \\
\hline & $\begin{array}{l}\text { Women } \\
\text { no Het. }\end{array}$ & $\begin{array}{l}\text { Women } \\
\text { with Het. }\end{array}$ & $\begin{array}{c}\text { Men } \\
\text { No Het. }\end{array}$ & $\begin{array}{c}\text { Men } \\
\text { with Het. }\end{array}$ \\
\hline INTERCEPT & $\begin{array}{c}-12.4185 * * * \\
(2.5686)\end{array}$ & $\begin{array}{c}-12.3885 * * * \\
(2.6801)\end{array}$ & $\begin{array}{c}-10.0783 * * * \\
(3.0605)\end{array}$ & $\begin{array}{c}-10.2732 * * * \\
(3.1411)\end{array}$ \\
\hline BASELINE SPLINE 1 & $\begin{array}{c}0.6269 * * * \\
(0.0529)\end{array}$ & $\begin{array}{c}0.6907 * * * \\
(0.0549)\end{array}$ & $\begin{array}{c}0.6620 * * * \\
(0.0624)\end{array}$ & $\begin{array}{c}0.7374 * * * \\
(0.0632)\end{array}$ \\
\hline BASELINE SPLINE 2 & $\begin{array}{c}-0.3557 * * * \\
(0.0448)\end{array}$ & $\begin{array}{c}-0.3248 * * * \\
(0.0465)\end{array}$ & $\begin{array}{c}-0.4961 * * * \\
(0.0574)\end{array}$ & $\begin{array}{c}-0.4679 * * * \\
(0.0583)\end{array}$ \\
\hline BASELINE SPLINE 3 & $\begin{array}{c}-0.2849 * * * \\
(0.0558)\end{array}$ & $\begin{array}{c}-0.2918 * * * \\
(0.0579)\end{array}$ & $\begin{array}{c}-0.3916 * * * \\
(0.0779)\end{array}$ & $\begin{array}{c}-0.4135 \text { *** } \\
(0.0793)\end{array}$ \\
\hline BASELINE SPLINE 4 & $\begin{array}{l}-0.0103 \\
(0.0420)\end{array}$ & $\begin{array}{c}-0.1021 * * \\
(0.0435)\end{array}$ & $\begin{array}{l}-0.0823 \\
(0.0610)\end{array}$ & $\begin{array}{c}-0.1258 * * \\
(0.0637)\end{array}$ \\
\hline BASELINE SPLINE 5 & $\begin{array}{c}-0.0828 * * \\
(0.0422)\end{array}$ & $\begin{array}{c}-0.1315 * * * \\
(0.0432)\end{array}$ & $\begin{array}{l}-0.0460 \\
(0.0484)\end{array}$ & $\begin{array}{c}-0.1197 * * \\
(0.0527)\end{array}$ \\
\hline BASELINE SPLINE 6 & $\begin{array}{c}0.1270 * * * \\
(0.0392)\end{array}$ & $\begin{array}{c}0.1402 * * * \\
(0.0404)\end{array}$ & $\begin{array}{c}0.1302 * * * \\
(0.0339)\end{array}$ & $\begin{array}{c}0.1509 * * * \\
(0.0354)\end{array}$ \\
\hline BASELINE SPLINE 7 & $\begin{array}{l}-0.0294 \\
(0.0199)\end{array}$ & $\begin{array}{c}-0.0484 * * \\
(0.0208)\end{array}$ & $\begin{array}{c}-0.0430 * * * \\
(0.0142)\end{array}$ & $\begin{array}{c}-0.0529 * * * \\
(0.0151)\end{array}$ \\
\hline AGE 1 & $\begin{array}{c}3.1555 * * \\
(1.3012)\end{array}$ & $\begin{array}{c}2.9833 * * \\
(1.3549)\end{array}$ & $\begin{array}{c}1.1020 \\
(1.6340)\end{array}$ & $\begin{array}{c}1.0293 \\
(1.6731)\end{array}$ \\
\hline AGE 2 & $\begin{array}{c}1.1397 * * * \\
(0.0912)\end{array}$ & $\begin{array}{c}1.1562 * * * \\
(0.0947)\end{array}$ & $\begin{array}{c}1.2974 * * * \\
(0.2068)\end{array}$ & $\begin{array}{c}1.2519 * * * \\
(0.2110)\end{array}$ \\
\hline AGE 3 & $\begin{array}{l}-0.0227 \\
(0.0286)\end{array}$ & $\begin{array}{c}0.1524 * * * \\
(0.0326)\end{array}$ & $\begin{array}{c}0.2038 * * * \\
(0.0493)\end{array}$ & $\begin{array}{c}0.2872 * * * \\
(0.0531)\end{array}$ \\
\hline AGE 4 & $\begin{array}{l}-0.0260 \\
(0.0257)\end{array}$ & $\begin{array}{c}0.1012 * * * \\
(0.0287)\end{array}$ & $\begin{array}{c}0.0057 \\
(0.0337)\end{array}$ & $\begin{array}{c}0.1403 * * * \\
(0.0431)\end{array}$ \\
\hline AGE 5 & $-0.1283 * * *$ & $-0.0762 * * *$ & $-0.0901 * * *$ & $-0.0490 * * *$ \\
\hline
\end{tabular}


Table 3b: Baseline Duration and Age Parameters - Union Transitions

\begin{tabular}{|c|c|c|c|c|}
\hline & $\begin{array}{c}\text { Model } 1 \\
\text { Women } \\
\text { no Het. }\end{array}$ & $\begin{array}{r}\text { Model } 2 \\
\text { Women } \\
\text { with Het. }\end{array}$ & $\begin{array}{c}\text { Model } 3 \\
\text { Men } \\
\text { no Het. }\end{array}$ & $\begin{array}{c}\text { Model } 4 \\
\text { Men } \\
\text { with Het. }\end{array}$ \\
\hline INTERCEPT & $\begin{array}{c}-7.2900 * * * \\
(0.8993)\end{array}$ & $\begin{array}{c}-7.4762 * * * \\
(0.8909)\end{array}$ & $\begin{array}{c}-9.4707 * * * \\
(3.2884)\end{array}$ & $\begin{array}{c}-9.6794 * * * \\
(3.1201)\end{array}$ \\
\hline BASELINE SPLINE2 & $\begin{array}{l}-0.0534 \\
(0.0909)\end{array}$ & $\begin{array}{l}-0.0116 \\
(0.0918)\end{array}$ & $\begin{array}{l}0.1778 * \\
(0.1011)\end{array}$ & $\begin{array}{c}0.2448 * * \\
(0.1083)\end{array}$ \\
\hline BASELINE SPLINE3 & $\begin{array}{c}-0.1366 * \\
(0.0797)\end{array}$ & $\begin{array}{l}-0.1173 \\
(0.0806)\end{array}$ & $\begin{array}{c}-0.3157 * * * \\
(0.1040)\end{array}$ & $\begin{array}{c}-0.2706 * * \\
(0.1056)\end{array}$ \\
\hline BASELINE SPLINE4 & $\begin{array}{c}0.0169 \\
(0.0685)\end{array}$ & $\begin{array}{c}0.0191 \\
(0.0702)\end{array}$ & $\begin{array}{l}-0.1397 \\
(0.1090)\end{array}$ & $\begin{array}{l}-0.1592 \\
(0.1107)\end{array}$ \\
\hline BASELINE SPLINE5 & $\begin{array}{c}-0.1276 * \\
(0.0663)\end{array}$ & $\begin{array}{l}-0.1081 \\
(0.0686)\end{array}$ & $\begin{array}{l}0.1587 * \\
(0.0895)\end{array}$ & $\begin{array}{c}0.1860 * * \\
(0.0948)\end{array}$ \\
\hline BASELINE SPLINE6 & $\begin{array}{c}0.1492 * * \\
(0.0603)\end{array}$ & $\begin{array}{l}0.1255 * \\
(0.0645)\end{array}$ & $\begin{array}{c}0.0203 \\
(0.0727)\end{array}$ & $\begin{array}{c}0.0299 \\
(0.0758)\end{array}$ \\
\hline BASELINE SPLINE7 & $\begin{array}{c}-0.1031 * * \\
(0.0424)\end{array}$ & $\begin{array}{l}-0.0415 \\
(0.0452)\end{array}$ & $\begin{array}{l}-0.0044 \\
(0.0333)\end{array}$ & $\begin{array}{l}0.0651 * \\
(0.0373)\end{array}$ \\
\hline BASELINE SPLINE8 & $\begin{array}{c}-0.0917 * * * \\
(0.0214)\end{array}$ & $\begin{array}{c}-0.0736 * * * \\
(0.0221)\end{array}$ & $\begin{array}{c}-0.0741 * * * \\
(0.0151)\end{array}$ & $\begin{array}{c}-0.0610 * * * \\
(0.0160)\end{array}$ \\
\hline AGE 1 & $\begin{array}{l}0.9541 * \\
(0.5071)\end{array}$ & $\begin{array}{l}0.8676 * \\
(0.5057)\end{array}$ & $\begin{array}{c}0.5689 \\
(1.7129)\end{array}$ & $\begin{array}{c}0.4458 \\
(1.6218)\end{array}$ \\
\hline AGE 2 & $\begin{array}{c}0.9627 * * * \\
(0.1106)\end{array}$ & $\begin{array}{c}1.0131 * * * \\
(0.1117)\end{array}$ & $\begin{array}{c}1.4589 * * * \\
(0.2106)\end{array}$ & $\begin{array}{c}1.4711 * * * \\
(0.2163)\end{array}$ \\
\hline AGE 3 & $\begin{array}{c}0.3519 * * * \\
(0.0593)\end{array}$ & $\begin{array}{c}0.4666 * * * \\
(0.0642)\end{array}$ & $\begin{array}{c}0.3188 * * * \\
(0.0804)\end{array}$ & $\begin{array}{c}0.3656 * * * \\
(0.0856)\end{array}$ \\
\hline AGE 4 & $\begin{array}{c}-0.2570 * * * \\
(0.0529)\end{array}$ & $\begin{array}{c}-0.1195 * * \\
(0.0581)\end{array}$ & $\begin{array}{l}-0.0310 \\
(0.0672)\end{array}$ & $\begin{array}{c}0.0522 \\
(0.0724)\end{array}$ \\
\hline AGE 5 & $\begin{array}{c}-0.0455 * * * \\
(0.0081)\end{array}$ & $\begin{array}{c}-0.0330 * * * \\
(0.0088)\end{array}$ & $\begin{array}{c}-0.0489 * * * \\
(0.0088)\end{array}$ & $\begin{array}{c}-0.0309 * * * \\
(0.0102)\end{array}$ \\
\hline
\end{tabular}


Table 3c: Baseline Duration and Age Parameters - Dissolution Transitions

\begin{tabular}{|c|c|c|c|c|}
\hline & $\begin{array}{c}\text { Model } 1 \\
\text { Women } \\
\text { no Het. }\end{array}$ & $\begin{array}{c}\text { Model } 2 \\
\text { Women } \\
\text { with Het. }\end{array}$ & $\begin{array}{c}\text { Model } 3 \\
\text { Men } \\
\text { no Het. }\end{array}$ & $\begin{array}{c}\text { Model } 4 \\
\text { Men } \\
\text { with Het. }\end{array}$ \\
\hline INTERCEPT & $\begin{array}{l}-1.8803 \\
(4.6208)\end{array}$ & $\begin{array}{l}-1.9192 \\
(5.3993)\end{array}$ & $\begin{array}{c}0.2287 \\
(1.9674)\end{array}$ & $\begin{array}{l}-1.4351 \\
(1.8116)\end{array}$ \\
\hline BASELINE SPLINE2 & $\begin{array}{c}0.0532 \\
(0.1061)\end{array}$ & $\begin{array}{c}0.0699 \\
(0.1110)\end{array}$ & $\begin{array}{c}0.0110 \\
(0.0894)\end{array}$ & $\begin{array}{c}0.0101 \\
(0.0922)\end{array}$ \\
\hline BASELINE SPLINE3 & $\begin{array}{l}-0.0071 \\
(0.0965)\end{array}$ & $\begin{array}{l}-0.0094 \\
(0.0975)\end{array}$ & $\begin{array}{c}0.0318 \\
(0.0357)\end{array}$ & $\begin{array}{c}0.0381 \\
(0.0389)\end{array}$ \\
\hline BASELINE SPLINE4 & $\begin{array}{l}-0.1430 \\
(0.0977)\end{array}$ & $\begin{array}{l}-0.1576 \\
(0.1009)\end{array}$ & $\begin{array}{l}-0.0174 \\
(0.0188)\end{array}$ & $\begin{array}{c}-0.0427 * \\
(0.0231)\end{array}$ \\
\hline BASELINE SPLINE5 & $\begin{array}{c}0.1725 * * \\
(0.0672)\end{array}$ & $\begin{array}{c}0.1651 * * \\
(0.0686)\end{array}$ & $(0.0466)$ & $(0.0519)$ \\
\hline BASELINE SPLINE6 & $\begin{array}{c}-0.1438 * * \\
(0.0733)\end{array}$ & $\begin{array}{c}-0.1617 * * \\
(0.0746)\end{array}$ & & \\
\hline BASELINE SPLINE7 & $\begin{array}{c}0.1403 * * \\
(0.0699)\end{array}$ & $\begin{array}{l}0.1272 * \\
(0.0708)\end{array}$ & & \\
\hline BASELINE SPLINE8 & $\begin{array}{c}-0.0393 * * \\
(0.0194)\end{array}$ & $\begin{array}{c}-0.0699 * * * \\
(0.0227)\end{array}$ & & \\
\hline AGE 1 & $\begin{array}{l}-0.7122 \\
(2.6040)\end{array}$ & $\begin{array}{l}-1.3114 \\
(3.0206)\end{array}$ & $\begin{array}{c}-0.6235 * \\
(0.3331)\end{array}$ & $\begin{array}{l}-0.4884 \\
(0.2971)\end{array}$ \\
\hline AGE 2 & $\begin{array}{c}0.0495 \\
(0.3175)\end{array}$ & $\begin{array}{c}0.1701 \\
(0.3613)\end{array}$ & $\begin{array}{c}-0.0178 * \\
(0.0097)\end{array}$ & $\begin{array}{c}0.0061 \\
(0.0162)\end{array}$ \\
\hline AGE 3 & $\begin{array}{c}-0.2782 * * * \\
(0.0644)\end{array}$ & $\begin{array}{c}-0.2014 * * * \\
(0.0702)\end{array}$ & & \\
\hline AGE 4 & $\begin{array}{c}0.0196 \\
(0.0536)\end{array}$ & $\begin{array}{l}0.1014 * \\
(0.0605)\end{array}$ & & \\
\hline AGE 5 & $\begin{array}{l}-0.0133 \\
(0.0097)\end{array}$ & $\begin{array}{c}0.0136 \\
(0.0144)\end{array}$ & & \\
\hline
\end{tabular}


Table 3d: Baseline Duration and Age Parameters - Employment Transitions

\begin{tabular}{lcccc}
\hline \hline & Model 1 & Model 2 & Model 3 & Model 4 \\
& Women & Women & Men & Men \\
& no Het. & with Het. & no Het. & with Het. \\
\hline INTERCEPT & $-7.2022 * * *$ & $-7.1866 * * *$ & $-7.3026 * * *$ & $-7.2898 * * *$ \\
& $(0.2657)$ & $(0.2648)$ & $(0.2985)$ & $(0.3001)$ \\
BASELINE SPLINE2 & $-0.6417 * * *$ & $-0.6281 * * *$ & $-0.7345 * * *$ & $-0.6316 * * *$ \\
& $(0.0372)$ & $(0.0379)$ & $(0.0424)$ & $(0.0486)$ \\
BASELINE SPLINE3 & 0.0167 & 0.0147 & -0.0529 & -0.0396 \\
& $(0.0371)$ & $(0.0375)$ & $(0.0517)$ & $(0.0532)$ \\
BASELINE SPLINE4 & $-0.1924 * * *$ & $-0.1890 * * *$ & $-0.5705 * * *$ & $-0.5543 * * *$ \\
& $(0.0378)$ & $(0.0382)$ & $(0.0505)$ & $(0.0513)$ \\
BASELINE SPLINE5 & $0.2388 * * *$ & $0.2430 * * *$ & $0.1725 * * *$ & $0.1920 * * *$ \\
& $(0.0341)$ & $(0.0347)$ & $(0.0504)$ & $(0.0530)$ \\
BASELINE SPLINE6 & $-0.1696 * * *$ & $-0.1636 * * *$ & -0.0681 & -0.0406 \\
& $(0.0450)$ & $(0.0454)$ & $(0.0700)$ & $(0.0723)$ \\
BASELINE SPLINE7 & -0.0838 & -0.0761 & $-0.5706 * * *$ & $-0.5421 * * *$ \\
& $(0.0561)$ & $(0.0568)$ & $(0.0968)$ & $(0.0981)$ \\
BASELINE SPLINE8 & $-0.0667 * * *$ & $-0.0688 * * *$ & $0.0725 * * *$ & $0.0899 * * *$ \\
& $(0.0195)$ & $(0.0201)$ & $(0.0202)$ & $(0.0223)$ \\
AGE 1 & $3.5138 * * *$ & $3.5029 * * *$ & $3.8419 * * *$ & $3.7580 * * *$ \\
AGE 2 & $(0.1406)$ & $(0.1406)$ & $(0.1581)$ & $(0.1611)$ \\
AGE 3 & $(0.2221 * * *$ & $0.2477 * * *$ & $0.3884 * * *$ & $0.4558 * * *$ \\
& $(0.0340)$ & $(0.0355)$ & $(0.0470)$ & $(0.0496)$ \\
& $-0.0658 * * *$ & $-0.0492 * *$ & $0.0584 * *$ & $0.0815 * * *$ \\
& $(0.0226)$ & $(0.0234)$ & $(0.0289)$ & $(0.0312)$ \\
& $0.1198 * * *$ & $0.1522 * * *$ & -0.0053 & 0.0427 \\
& $(0.0231)$ & $(0.0247)$ & $(0.0290)$ & $(0.0309)$ \\
& $-0.0277 * * *$ & $-0.0273 * * *$ & $-0.0349 * * *$ & $-0.0389 * * *$ \\
& $(0.0031)$ & $(0.0032)$ & $(0.0038)$ & $(0.0042)$ \\
\hline \hline & & & & \\
& & & & \\
& & &
\end{tabular}


Table 3e: Baseline Duration and Age Parameters - Non-Employment Transitions

\begin{tabular}{lcccc}
\hline \hline & Model 1 & Model 2 & Model 3 & Model 4 \\
Women & Women & Men & Men \\
& no Het. & with Het. & no Het. & with Het. \\
\hline INTERCEPT & -2.3605 & -2.7731 & -2.0553 & -3.1517 \\
& $(1.6328)$ & $(1.9251)$ & $(1.9268)$ & $(1.9401)$ \\
BASELINE SPLINE2 & $-0.2229 * * *$ & $-0.1037 * * *$ & $-0.6186 * * *$ & $-0.4941 * * *$ \\
& $(0.0375)$ & $(0.0390)$ & $(0.0499)$ & $(0.0529)$ \\
BASELINE SPLINE3 & $-0.1687 * * *$ & $-0.1819 * * *$ & $-0.1139 *$ & $-0.1274 * *$ \\
& $(0.0421)$ & $(0.0433)$ & $(0.0611)$ & $(0.0624)$ \\
BASELINE SPLINE4 & 0.0425 & 0.0330 & -0.0665 & -0.0694 \\
& $(0.0486)$ & $(0.0513)$ & $(0.0717)$ & $(0.0726)$ \\
BASELINE SPLINE5 & -0.0105 & -0.0104 & -0.0801 & -0.0851 \\
& $(0.0390)$ & $(0.0418)$ & $(0.0590)$ & $(0.0596)$ \\
BASELINE SPLINE6 & 0.0277 & 0.0586 & -0.0383 & -0.0399 \\
& $(0.0465)$ & $(0.0498)$ & $(0.0691)$ & $(0.0693)$ \\
BASELINE SPLINE7 & -0.0567 & -0.0284 & -0.0481 & -0.0588 \\
& $(0.0490)$ & $(0.0519)$ & $(0.0597)$ & $(0.0606)$ \\
BASELINE SPLINE8 & $0.0421 * * *$ & $0.0622 * * *$ & $0.0522 * * *$ & $0.0550 * * *$ \\
& $(0.0127)$ & $(0.0151)$ & $(0.0091)$ & $(0.0104)$ \\
AGE 1 & -0.5064 & -0.5891 & -0.6417 & -0.3823 \\
AGE 2 & $(0.8365)$ & $(0.9787)$ & $(0.9878)$ & $(0.9927)$ \\
AGE 3 & $0.4345 * * *$ & $0.4341 * * *$ & $0.3749 * * *$ & $0.3416 * * *$ \\
& $(0.0781)$ & $(0.0809)$ & $(0.0800)$ & $(0.0843)$ \\
& 0.0378 & $0.1070 * * *$ & 0.0457 & $0.0965 * * *$ \\
& $(0.0248)$ & $(0.0275)$ & $(0.0299)$ & $(0.0340)$ \\
& $-0.1868 * * *$ & $-0.0798 * * *$ & $-0.0847 * *$ & $-0.0612 *$ \\
& $(0.0236)$ & $(0.0263)$ & $(0.0335)$ & $(0.0365)$ \\
& $-0.0321 * * *$ & $-0.0133 * * *$ & $0.0275 * * *$ & $0.0411 * * *$ \\
& $(0.0036)$ & $(0.0044)$ & $(0.0057)$ & $(0.0070)$ \\
\hline \hline
\end{tabular}




\section{Table 4: Unobserved Heterogeneity}

\section{S. D. Of Unobserved Heterogeneity Terms}

\begin{tabular}{lcc}
\hline \hline & Model 2 & Model 4 \\
& WOMEN & MEN \\
\hline FERTILITY: & $0.9430 * * *$ & $0.7913 * * *$ \\
UNION FORMATION: & $(0.0463)$ & $(0.0696)$ \\
& $0.8396 * * *$ & $0.7776 * * *$ \\
UNION DISSOLUTION: & $(0.0703)$ & $(0.0868)$ \\
& $0.8333 * * *$ & $0.8036 * * *$ \\
EMPLOYMENT: & $(0.2175)$ & $(0.2268)$ \\
& $0.2214 * * *$ & $0.4221 * * *$ \\
NON-EMPLOYMENT: & $(0.0454)$ & $(0.0416)$ \\
& $0.9711 * * *$ & $0.8517 * * *$ \\
& $(0.0410)$ & $(0.1005)$ \\
\hline \hline
\end{tabular}

Correlations Between Unobserved Heterogeneity Terms

\begin{tabular}{lcc}
\hline \hline & Model 2 & Model 4 \\
& WOMEN & MEN \\
\hline FERTILITY \& UNION FORMATION: & $0.4809 * * *$ & $0.5460 * * *$ \\
FERTILITY \& DISSOLUTION: & $(0.0567)$ & $(0.0886)$ \\
FERTILITY \& EMPLOYMENT: & $0.2525 * *$ & $0.2852 *$ \\
FERTILITY \& NON-EMPLOYMENT: & $(0.0989)$ & $(0.1500)$ \\
& $0.4548 * * *$ & $0.2717 * * *$ \\
UNION FORMATION \& DISSOLUTION: & $(0.1326)$ & $(0.0890)$ \\
& $0.5632 * * *$ & $0.1239 *$ \\
UNION \& EMPLOYMENT: & $(0.0400)$ & $(0.0693)$ \\
UNION \& NON-EMPLOYMENT: & $(0.1228)$ & 0.3221 \\
& $0.7789 * * *$ & $(0.2094)$ \\
DISSOLUTION \& EMPLOYMENT: & $(0.1395)$ & $(0.0996)$ \\
& $0.0876 *$ & -0.0806 \\
DISSOLUTION \& NON-EMPLOYMENT: & $(0.0487)$ & $(0.0721)$ \\
EMPLOYMENT \& NON-EMPLOYMENT: & 0.0031 & -0.2513 \\
& $(0.1652)$ & $(0.1641)$ \\
& $0.5088 * * *$ & $0.5262 * * *$ \\
\hline \hline
\end{tabular}


Table 5: Descriptive statistics from simulations, women

\begin{tabular}{lcccc}
\hline \hline & Baserun & $\begin{array}{c}\text { Fertility } \\
\text { increased }\end{array}$ & $\begin{array}{c}\text { Union } \\
\text { increased }\end{array}$ & $\begin{array}{c}\text { Employment } \\
\text { increased }\end{array}$ \\
\hline proportion first birth by age 18 & 0.069 & 0.190 & 0.079 & 0.067 \\
proportion first birth by age 20 & 0.188 & 0.401 & 0.222 & 0.184 \\
proportion first birth by age 22 & 0.310 & 0.564 & 0.371 & 0.311 \\
proportion first birth by age 24 & 0.425 & 0.681 & 0.489 & 0.426 \\
proportion first birth by age 26 & 0.509 & 0.751 & 0.571 & 0.509 \\
proportion first birth by age 28 & 0.577 & 0.801 & 0.632 & 0.576 \\
proportion first birth by age 30 & 0.622 & 0.828 & 0.675 & 0.621 \\
proportion first birth by age 32 & 0.648 & 0.842 & 0.698 & 0.646 \\
proportion first birth by age 34 & 0.663 & 0.850 & 0.713 & 0.663 \\
proportion first birth by age 36 & 0.673 & 0.855 & 0.721 & 0.672 \\
\hline proportion second birth by age 22 & 0.137 & 0.361 & 0.177 & 0.136 \\
proportion second birth by age 24 & 0.242 & 0.520 & 0.295 & 0.242 \\
proportion second birth by age 26 & 0.334 & 0.624 & 0.390 & 0.334 \\
proportion second birth by age 28 & 0.397 & 0.684 & 0.452 & 0.396 \\
proportion second birth by age 30 & 0.441 & 0.721 & 0.494 & 0.440 \\
proportion second birth by age 32 & 0.470 & 0.742 & 0.523 & 0.469 \\
proportion second birth by age 34 & 0.489 & 0.754 & 0.540 & 0.487 \\
proportion second birth by age 36 & 0.501 & 0.761 & 0.551 & 0.500 \\
proportion second birth by age 38 & 0.509 & 0.766 & 0.558 & 0.507 \\
proportion second birth by age 40 & 0.514 & 0.768 & 0.562 & 0.512 \\
\hline Mean time spent in union in years & 15.38 & 15.74 & 18.15 & 15.34 \\
Mean time spent single & 12.30 & 11.93 & 9.53 & 12.34 \\
Mean time spent not working & 11.71 & 13.51 & 12.40 & 11.07 \\
Mean time spent working & 15.94 & 14.15 & 15.26 & 16.59 \\
\hline \hline
\end{tabular}


Table 6: Descriptive statistics from simulations, Men

\begin{tabular}{lcccc}
\hline \hline & Baserun & $\begin{array}{c}\text { Fertility } \\
\text { increased }\end{array}$ & $\begin{array}{c}\text { Union } \\
\text { increased }\end{array}$ & $\begin{array}{c}\text { Employment } \\
\text { increased }\end{array}$ \\
\hline proportion first birth by age 18 & 0.018 & 0.049 & 0.020 & 0.018 \\
proportion first birth by age 20 & 0.057 & 0.138 & 0.071 & 0.059 \\
proportion first birth by age 22 & 0.123 & 0.262 & 0.167 & 0.129 \\
proportion first birth by age 24 & 0.219 & 0.405 & 0.294 & 0.228 \\
proportion first birth by age 26 & 0.312 & 0.519 & 0.405 & 0.322 \\
proportion first birth by age 28 & 0.403 & 0.610 & 0.503 & 0.416 \\
proportion first birth by age 30 & 0.471 & 0.669 & 0.569 & 0.484 \\
proportion first birth by age 32 & 0.511 & 0.702 & 0.606 & 0.526 \\
proportion first birth by age 34 & 0.537 & 0.721 & 0.630 & 0.552 \\
proportion first birth by age 36 & 0.555 & 0.733 & 0.645 & 0.571 \\
\hline proportion second birth by age 24 & 0.091 & 0.243 & 0.136 & 0.094 \\
proportion second birth by age 26 & 0.166 & 0.371 & 0.235 & 0.175 \\
proportion second birth by age 28 & 0.236 & 0.467 & 0.318 & 0.247 \\
proportion second birth by age 30 & 0.297 & 0.534 & 0.383 & 0.309 \\
proportion second birth by age 32 & 0.341 & 0.577 & 0.424 & 0.353 \\
proportion second birth by age 34 & 0.368 & 0.603 & 0.451 & 0.381 \\
proportion second birth by age 36 & 0.387 & 0.620 & 0.467 & 0.400 \\
proportion second birth by age 38 & 0.400 & 0.630 & 0.478 & 0.415 \\
proportion second birth by age 40 & 0.408 & 0.637 & 0.486 & 0.423 \\
\hline Mean time spent in union in years & 12.67 & 13.70 & 15.99 & 13.40 \\
Mean time spent single & 14.52 & 13.93 & 11.20 & 14.48 \\
Mean time spent not working & 6.64 & 6.98 & 6.66 & 4.15 \\
Mean time spent working & 20.50 & 20.59 & 20.46 & 23.68 \\
\hline \hline
\end{tabular}

